
Afkār Vol. 19 Special Issue (2017): 1-46

\title{
KEAUTORITARIAN MANHAJ AHL AL-SUNNAH WA AL-JAMĀ'AH: INDUK DAN BENTENG AKIDAH UMMAH
}

AUTHORITATIVE APPROACH OF AHL AL-SUNNAH WA AL-JAMĀ'AH: A FUNDAMENTAL AND BASTION OF MUSLIMS FAITH

\section{Azmil Zainal Abidin}

Department of 'Aqidah \& Islamic Thought. Academy of Islamic Studies. University of Malaya. 50603. Kuala Lumpur. Malaysia.

Emel: hadiqah_irfan@um.edu.my

\begin{abstract}
Khulasah
Ahl al-Sunnah wa al-Jamā’ah adalah aliran arus perdana umat Islam kontemporari. Ia beridentitikan pegangan yang kental terhadap konsep kesabitan sifat Allah atau Sifătiyyah sebagaimana ia merangkumi kelompok ulama dalam segenap disiplin ilmu Islam yang muktabar. Artikel ini bertujuan menjelaskan aspek keautoritian manhaj Ahl al-Sunnah wa alJamā'ah, khususnya dalam bidang akidah. Kajian mendapati bahawa manhaj ini bukan sahaja bercirikan keilmiahannya dalam berinteraksi dengan nas agama tetapi juga bercirikan kejelasan piawaiannya berhubung tahap intipati ajaran Islam yang muktabar. Keistimewaan manhaj ini juga terserlah dari aspek kesederhanaannya dalam mengimbangi keunggulan wahyu dengan potensi akal dalam mengkhidmati kebenaran yang bersumberkan wahyu tersebut. Kematangan wacana manhaj Ahl alSunnah wa al-Jamā'ah ini melayakkannya menjadi induk atau paksi kesatuan ummah dan benteng atau perisai kemurnian akidah mereka.
\end{abstract}

Kata kunci: usuluddin; ilmu kalam; manhaj Ahl alSunnah wa al-Jamā’ah; kemurnian akidah. 


\begin{abstract}
Ahl al-Sunnah wa al-Jamā'ah (Sunni) is the main denomination held by contemporary Muslims. Among its identities is the firmly belief in the concept of Allah's attributes. It also places and gathers various groups of ulam $\bar{a}$ ' in various disciplines of recognized sciences. This article aims to explain the aspects of the authority of Ahl alSunnah wa al-Jamā'ah, especially in the discipline of faith. The study concludes that this manhaj has a scientific feature in interacting with the religious texts (nașs) while having a precise and clear standard in achieving the truth. Its special feature is also manifested by the aspect of its modesity in balancing the superiority of the revelation with the potential of reason. The maturity of the discourse of Ahl alSunnah wa al-Jamā'ah qualified it as the fundamental and bastion of Muslims faith.
\end{abstract}

Keywords: Usuluddin; kalam; manhaj Ahl alSunnah wa al-Jamā'ah; the purity of the creed.

\title{
Pendahuluan
}

Sejak berperanan di atas muka bumi, Islam menerima asakan yang belum pernah dialami oleh agama lain. Terdapat agama yang pernah menakluk dunia dan menundukkan umat serta tamadun lain, namun ia gagal menghadapi serangan yang jauh lebih ringan daripada apa yang terpaksa dihadapi oleh Islam. Islam bukan sekadar berjaya menangkis serangan tersebut, bahkan mampu mengekalkan ketulenan ciri-ciri dan rohnya yang asli. Walaupun sentiasa diancam aliran faham yang merosakkan, agenda musuh itu pasti berjaya ditangani melalui jihad keilmuan. Natijahnya, kemurnian akidah tetap kekal terpelihara menurut kerangka ilmu para ulama dalam memahami al-Qur'ān dan al-Hadīth. ${ }^{1}$

\footnotetext{
${ }^{1}$ Abū al-Hasan 'Alī al-Nadawī, Rijāl al-Fikr wa al-Da ‘wah fì al-Islām (al-Juz'u al-Awwal) (Kuwait: Dār al-Qalam, 1989), 11-15.
} 
Prinsip keilmiahan manhaj adalah rahsia utama kekebalan Islam dalam menghadapi ancaman ajaran dan kefahaman asing. Sebagai aliran arus perdana yang dominan dan muktabar, Ahl al-Sunnah wa al-Jamā'ah layak diperakukan sebagai mewakili manhaj Islam yang ilmiah ini. Melalui tempoh masa dan tahap perkembangan tertentu, sikap responsif terhadap bidaah iktikad yang muncul sejak zaman salaf, aliran ini dikenali kemudiannya secara formal sebagai Ahl al-Sunnah wa al-Jamā’ah.

\section{Definisi Akidah}

Lafaz akidah adalah terbitan daripada al- 'aqd yang bererti "simpulan ikatan" sebagai lawan bagi "rungkaian" (alaqd naqie al-hall). ${ }^{2}$ Walaupun "ikatan" itu kebiasaannya tergambar pada perkara material - yang konkrit dan inderawi -, namun ia turut terpakai kepada "ikatan maknawi - yang abstrak -" secara peluasan majaz. Justeru, akidah menurut istilah adalah "simpulan ikatan yang teguh antara peribadi yang mempercayai dengan apa yang dipercayanya" (al-rabt al-wathīq bayn al-shakht almu ‘taqid wa al-shay' al-mu 'taqad fih). Pengistilahannya sebagai akidah Islam pula merujuk kepada hubungan teguh antara seseorang terhadap topik akidah Islam yang utama berhubung ketuhanan, kenabian dan perkara ghaib (al-sam iyyāt). ${ }^{3}$

${ }^{2}$ Qandīl Muhammad Qandīl, Taḥlīl wa Takmīl: al-Iqtiṣād fì al-I tiqād (Kaherah: Dār al-Ṭibā’ah al-Muhammadiyyah, 1991), 13.

${ }^{3}$ Lajnah min asātizah Qism al-'Aqīdah wa al-Falsafah bi Kulliyyah Ușūl al-Dīn - Jāmi ah al-Azhar, Ușūl al- 'Aqīdah al-Islāmiyyah wa al-Akhlāq (al-Dirāsah: Maktabah al-Azhar, 1972), 17. Al-sam iyyāt juga dinamakan al-ghaybiyyāt kerana ia diterima daripada jalan pendengaran (al-sam 'u) iaitu jalan syarak melalui wahyu yang terpelihara (ma șüm). Manusia tidak mengetahui perkara sam ‘yyāt melainkan dari pihak syarak. Hakikat perkara ghaib hanya diketahui oleh Allah SWT. Ḥassan `Abd al-Ghazānī, Dirāsāt fì al- 'Aqīdah alIslāmiyyah: al-Sam ìyyāt (Kaherah: Mațba`ah al-Ḥusayn alIslāmiyyah, 1998), 11. 
Tabiat kedinamikan akidah dan kesan pengaruhnya terhadap individu tergambar sebagai "tanggapan (idrāk) yang jazam terhadap pandangan atau prinsip tertentu yang sampai kepada jiwa seseorang, lalu diterima dan diyakini, lantas menjadi sebahagian identiti dirinya yang bereaksi bersama-sama sensitivitinya yang halus dan mendalam. Kemudian, ia menggerakkan perasaan dan iradatnya, lantas mendorongnya kepada penunaian amalan yang adakalanya menuntut pengorbanan demi mempertahankan prinsip itu". 4

Tunjangan akidah sebagai prinsip hidup seseorang amat berkait rapat dengan syarat asas bagi kesahihannya yang bertolak daripada dalil yang meyakinkan. Justeru, akidah turut ditakrifkan sebagai "perkara yang dibenarkan oleh hati dan ditenangi oleh jiwa dengan pembenaran yang terbit daripada dalil meyakinkan tanpa sebarang keraguan"; 5 juga sebagai "ketetapan pegangan kepercayaan kepada Tuhan dan kepada rasul-rasulNya daripada beberapa simpulan atau ikatan kepercayaan dengan segala dalil-dalil supaya diperoleh iktikad yang yakin, kepercayaan yang putus sekira-kira menaikkan perasaan bekerja dan beramal menurut kepercayaan itu". 6 Firman Allah dalam surah Ibrahim, ayat 24:

${ }^{4}$ Qandīl, Taḥlīl wa Takmīl: al-Iqtiṣād fi al-I 'tiqād, 13.

5 Sa`d al-Dīn al-Sayyid Șālih, al-'Aqīdah al-Islāmiyyah fì Daw' al-'Ilm al-Hadìth (Kaherah: Dār al-Șafā, 1991), 14-15. Secara umum, Ahl al-Sunnah bersepakat melihat bahawa iman secara taklid tanpa dalil dianggap Mukmin yang berdosa, lantaran kecuaiannya, sedangkan ia mampu mempelajarinya. Secara terperinci pula, terdapat enam pendapat tentangnya. Lihat Aḥmad bin Muḥammad al-Sāwī, Kitāb Sharh al-Ṣāwī alā Jawharah al-Tawhīd (Beirut: Dār Ibn Kathīr, 2005), 109-112.

6. Abd al-Ghan̄̄ Yaḥyā \& 'Umar Yūsuf, Risālah al-Tawhì̄d ( t.tp: t.pt., t.th.), 5 . 


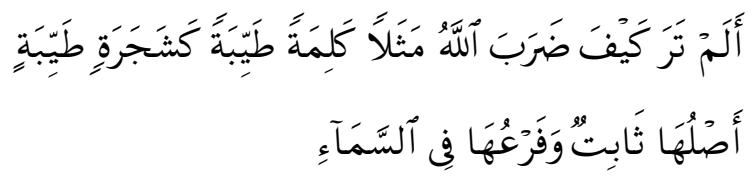

Terjemahan: Tidakkah engkau melihat (wahai Muhammad) bagaimana Allah mengemukakan satu perbandingan: kalimah yang baik adalah seperti sebatang pohon yang baik, yang akar tunjangnya tetap teguh, dan cabang pucuknya menjulang ke langit.

Akidah dalam erti kata iman atau kepercayaan yang teguh terhadap perkhabaran baginda SAW dapat difahami skema pentahapannya melalui tiga peringkat iaitu:

i. Paling rendah iaitu iman taklid bagi sesiapa yang menerima kata-kata orang lain tanpa sandaran dalil. Status iman ini diperselisihkan oleh para ulama.

ii. Al-ìmān al- 'aqlī yang terbina melalui dalil. Iman ini adalah muktabar. Ia tertera melalui aspek mengenal Allah SWT berserta sifat, nama dan perbuatanNya, mengenal rasulNya secara akliah (hukum akal yang pasti - wajib, mustahil dan harus) berdasarkan iktikad Ahl al-Sunnah wa al-Jamā'ah. ${ }^{7}$

iii. Al-ìmān al-dhawqī al-qalbī iaitu iktikad yang telah difahami oleh akal itu sampai ke dalam hati, lantas menyinari dan menghidupkannya. Inilah iman para siddīqin. ${ }^{8}$

Khusus mengenai al-ìmān al-'aqlī, akidah keimanan di tahap kedua ini menuntut pembebasan daripada unsur syak, zann, wahm serta iman taklid. Sebelum mencapai tahap al-īmān al-dhawqī yang menapak secara rasaan hati,

7 Sa`ìd Hawwā, Tarbiyyatunā al-Rūḥiyyah (Beirut \& Amman: Dār 'Ammār, 1989), 35.

8 Sa`̄id Hawwā, al-Asās fi al-Sunnah wa Fiqhihā: al- 'Aqā̄id alIslāmiyyah (al-mujallad al-awwal) (Shāri` al-Azhar: Dār al-Salām, 1992), 243. 
keimanan perlu melepasi syubhah bidaah iktikad yang muncul sepanjang zaman. Dalam membentengi kemurniaan akidah ini terbentuklah manhaj Ahl al-Sunnah wa al-Jamā’ah melalui panduan ilmu dan pemikiran yang tersusun-atur sehingga kebenaran dapat diasingkan daripada kepalsuan.

Sebagai disiplin Islam yang utama, ilmu akidah turut diistilahkan sebagai ilmu tauhid, ilmu usuluddin, ilmu kalam dan ilmu al-fiqh al-akbar (fiqah yang lebih besar) sempena konteks pengertiannya masing-masing. Ilmu akidah merujuk kepada "kaedah atau hukum syarak berbentuk iktikad yang dituntut ke atas mukallaf untuk beriktikad dan mengimani kesahihannya". Ilmu tauhid adalah "ilmu yang berpaksikan keesaan Allah SWT sebagai topik perbincangannya yang paling masyhur dan termulia". Ilmu usuluddin bererti "kajian ilmu berhubung asas hukum-hakam iktikad yang diambil daripada agama Islam". Ilmu kalam pula diistilahkan sedemikian sempena orientasi perbahasannya dalam meneguhkan hujah dan menundukkan lawan yang melibatkan unsur pendalilan mantik. $^{10}$

9 Di antaranya, al-Luma 'fì al-Radd 'alā ahl al-Zaygh wa al-Bida' karya al-Ash 'arī (m 330H), al-Insāf fì Mā Yajib I 'tiqāduhu wa Mā Lā Yajūz al-Jahl bihi karya al-Bāqillanī (m 403H), Kitāb Ușūl al-Dīn karya 'Abd al-Qāhir al-Baghdād̄̄ (m 429H), Kitāb al-Irshād ilā Qawāti al-Adillah fì Ușūl al-I'tiqād karya Imam al-Haramayn alJuwayni (m 478H), al-Iqtisād fì al-I'tiqūd karya al-Ghazālī (m 505H), Nihāyah al-Iqdām fì 'Ilm al-Kalām karya 'Abd al-Karim alShahrastānī (m 548H), Ma àlim Usūul al-Dīn karya Fakhr al-Din alRāzi (m 606H), Abkār al-Afkār fi Ușūl al-Dīn karya Sayf al-Dīn alĀmidī (m 631H), Rasā ìl fì al-Tawhīd karya al-'Izz bin `Abd alSalām (m 660H), Kitāb Miṣbāh al-Arwāh fị Ușūl al-Dīn karya alBayḍāwīi(m 685H) dan 'Aqīdah Ahl al-Tawhīd al-Kubrā karya alSanūsī (m 895H).

${ }^{10}$ Hasan Maḥmūd al-Shāfí `ô, al-Madkhal ilā Dirāsah 'Ilm al-Kalām (Kaherah: Maktabah Wahbah, 1991), 25-33. 

Afkār Vol. 19 Special Issue (2017): 1-46

\section{Identiti Ahl al-Sunnah wa al-Jamā’ah}

Kemunculan Ahl al-Sunnah wa al-Jamā'ah selepas kewafatan Rasulullah SAW dari aspek pengistilahannya bukan bermakna ia terpisah daripada ajaran baginda. Sebaliknya, Ahl al-Sunnah wa al-Jamā'ah berkesinambungan dengan sikap kesetiaan terhadap prinsip hidup baginda SAW dan para sahabat yang sedia wujud bersama-sama kelahiran Islam itu sendiri. ${ }^{11}$ Pesanan baginda SAW melalui al-ḥadith riwayat Abū Dāwud: ${ }^{12}$

$$
\text { فعليكم بسنتي وسنة الخلفاء الراشدين المهديين }
$$

Terjemahan: Hendaklah kalian mengikut sunnahku dan sunnah Khulafā' al-Rāshidin yang mendapat petunjuk - kalian berpegang dengannya.

Sabda baginda lagi melalui al-Hadīth riwayat al-Ṭabrāni: ${ }^{13}$

$$
\begin{aligned}
& \text { لن بتمتع أمتي على الضلالة فعليكم بالجماعة فإن يد الله } \\
& \text { على الجماعة }
\end{aligned}
$$

${ }^{11}$ Contohnya, Mu tazilah mendakwa bahawa iradat Allah SWT hanya berkait dengan perbuatan taat, manakala perbuatan kufur dan maksiat tidak terjadi berserta iradatNya. Kekufuran dan kemaksiatan yang diakukan oleh manusia adalah tidak dikehendaki olehNya. Tatkala itu, Ahl al-Sunnah menolak fahaman Mu`azilah ini, sebaliknya memahami bahawa segala kejadian itu berlaku menurut iradat Allah SWT. Apa yang dikehendakiNya pasti terjadi, manakala apa yang tidak dikehendakiNya tidak akan terjadi. Bagi Ahl alSunnah, inilah iktikad generasi salaf. Lihat Ismā'īl bin Mūsā alHāmīdī, Hawash ‘alā Sharh al-Kubrā li al-Sanūsī (Miṣr: Maṭba`ah Muștafā al-Bābīal-Halabī, 1936), 51-52.

12 Abū Dāwud Sulaymān bin Ash `ath al-Azadī al-Sajustān̄̄, Awwal Kitāb al-Sunnah, Bāb fì Luzūm al-Sunnah, al-Hadīth no. 4607, Mawsu àt al-Hadīth al-Sharīf al-Kutub al-Sittah (Riyadh: Dār alSalām, 2000), 1561.

13 Abū al-Qāsim Sulaymān bin Aḥmad al-Ṭabrānī, Bāb al-'Ayn, alHadīth no. 13623, al-Mu jam al-Kabīr (juz' 10) (t.tp.: Maktabah alAșālah wa al-Turāth, 2010), 3334. 
Terjemahan: Tidak sekali-kali berhimpun umatku di atas kesesatan. Maka hendaklah kamu berada di dalam jamaah. Maka sesungguhnya, 'tangan' Allah berada di atas jamaah.

Identiti asas Ahl al-Sunnah wa al-Jamā'ah merujuk kepada pendirian mereka dalam isu ketuhanan. Tatkala Mu`tazilah dikenali sebagai Mu’ațtilah yang menafikan sifat - ma 'ān $\bar{\imath}$ - Allah SWT, maka Ahl al-Sunnah wa alJamā'ah pula dikenali sebagai Șifātiyyah yang menetapkan sifatNya. Șifătiyyah adalah salaf atau generasi awal Ahl al-Sunnah yang mensabitkan sifatNya yang warid melalui syarak. ${ }^{14}$ Sebelum terbentuknya struktur ilmu kalam al-Ash arī dalam membela Șifătiyyah, ahli al-Hadīth telah terlebih dahulu menghadapi Qadariyyah dan Jahmiyyah awalan yang mentakwil ayat mutashābihah berhakimkan akal. Ketika Jahmiyyah dan Qadariyyah menafikan sifat dhätiyyah dan fi liyyah Allah, maka ahli al-Hadīth pula mensabitkannya ${ }^{15}$ sebagai mazhab Sifatiyyah sebelum ianya turut disabitkan oleh mutakallimīn Șifātiyyah. ${ }^{16}$

Ketika fitnah Jahmiyyah berleluasa menyebarkan ta țìl, mengingkari sifat Allah SWT dan mendakwa kemakhlukan al-Qur'ān, muncul tokoh-tokoh seperti Imam Mālik, Sufyān bin `Uyaynah dan `Abd Allāh bin al-

14 -Abd al-Qāhir bin Tāhir bin Muhammad al-Baghdādī, al-Farq bayn al-Firaq (Maydān al-Azhar: Maktabah Muhammad 'Alī Șubayh wa awlāduh, t.th.), 313, Muhammad bin `Abd al-Karīm bin Abū Bakr Aḥmad al-Shahrastānī, al-Milal wa al-Niḥal (Beirut: Dār al-Kutub al-'Ilmiyyah, 2001), 104-106 dan 'Alī Sāmī al-Nashshār, Nash'ah al-Fikr al-Falsafi fi al-Islām (jil. 1) (Kaherah: Dār al-Ma ārif, t.th.), 265.

15 Jalāl Muhammad Mūsā, Nash'ah al-Ash ariyyah wa Taṭawwuruhā (Beirut: Dār al-Kutub al-Lubnān̄̄, 1975), 115.

16 Hasan al-Huwaynī, Qaḍiyyah al-Sifāt al-Ilahiyyah wa Atharuhā fì Tasha ub al-Madhāhib wa Ikhtilāf al-Firaq (al-Sayyidah Zaynab: Dār al-Hudā, 1986), 98. 
Mubārak yang mendedahkan kesesatan pendapat itu serta percanggahannya dengan nas-nas al-Qur'ān dan al-Sunnah yang jelas itu. ${ }^{17}$ Sebilangan besar ulama salaf pada kurun ketiga dan keempat telah mengarang sejumlah karya dalam membidasnya, sekaligus membela akidah Ahl alSunnah wa al-Jamā’ah. ${ }^{18}$

Ahl al-Sunnah dinamakan kumpulan yang selamat (firqah näjiyah), lantaran kesempurnaan ikutan mereka terhadap Nabi SAW dan sahabat berhubung akidah tanpa melampaui pernyataan nas, bukan berpegang kepada akal semata-mata. Sebaliknya, aliran kumpulan yang lain dianggap sesat kerana mereka meninggalkan ikutan terhadap Nabi SAW dan sahabat serta menyalahi Ahl alSunnah, juga disebabkan mereka melampaui pernyataan nas dengan pentakwilan secara salah, lantas menuruti hawa nafsu yang menyalahi keterangan nas dan kejelasan akal. $^{19}$

Identiti asas Ahl al-Sunnah wa al-Jamā'ah juga merujuk kepada metodologi mereka dalam berinteraksi dengan sumber agama. Paksi keIslaman dan pegangan kebenaran yang dianjurkan olehnya dimaknakan dengan al-Jamāah. Kemurnian akidah Ahl al-Sunnah wa alJamā'ah adalah memenuhi syarat dan berdasarkan kefahaman yang sahih. Mereka memiliki akidah, mazhab ușüliyyah - berhubung asas agama - dan fiqahiyyah berhubung cara kefahaman - yang terhimpun dalam

17 Aḥmad bin Hanbal, al-Bukhāriyy, Ibn Qutaybah \& al-Dārimiyy, ‘Aqā’id al-Salaf, sunt. 'Alī Sāmī al-Nashshār \& `Ammar Jām `i alTTālibī (Iskandariah: Mansha'ah al-Ma`ārif, 1971), 7.

${ }^{18}$ Di antaranya ialah Ahmad bin Hanbal (m $241 \mathrm{H}$ ), Muhammad bin Ismā'īl al-Bukhārī (m 256 H), ’Ábd Allāh bin Muslim bin Qutaybah (m 276 H), 'Uthmān bin Sa id al-Dārimī (m 280 H) dan Muḥammad bin Ishaq bin Khuzaymah (m $311 \mathrm{H})$. Lihat ibid., h. 5 \& 6.

19 Muhammad Wahbī bin Husayn Afandī, al-'Aqā'id al-Khayriyyah (t.tp.: Dār Ihyā', t.th.), 7. 
keimanan terhadap al-Kitab dan al-Sunnah serta garis panduan dalam memahami kedua-duanya. ${ }^{20}$

Kombinasi lafaz al-jamā ah dengan al-sunnah juga adalah bersempena penerimaan aliran ini terhadap sumber dan dalil al-Kitāb Allah, al-Sunnah, ijmak ummah dan alqiyās, lantas tersisihlah Khawārij, Shīah Rawāfị̣ dan Mu`tazilah yang tidak bersedia menerima keautoritian hujah ijmak. $^{21}$

Ahl al-Sunnah wa al-Jamā’ah adalah sebaik-baik manifestasi yang lengkap bagi kefahaman Rasulullah SAW dan ijtihad sahabat RA dalam mentafsir dan mentakwil al-Qur'ān. Mereka beriltizam dengan sistem keilmuan yang dibina di atas penyelarasan teliti di antara hukum akal dengan penunjukan (dilālah) naqli; ${ }^{22}$ juga kaedah tatabahasa Arab yang muktamad dalam pentafsiran nas. Inilah titik penentu yang melayakkan mereka berhak menyandang kemuliaan sebagai Ahl al-Sunnah wa alJamā'ah. ${ }^{23}$

Manhaj Ahl al-Sunnah wa al-Jamā'ah mengambil kira panduan epistemologi $i^{24}$ berhubung aspek

${ }^{20}$ Sa`īd Hawwā, al-Asās fì al-Sunnah wa Fiqahuhā (jil. 1), 474 \& 475.

${ }^{21}$ Jalāl, Nash'ah al-Ash 'ariyyah wa Tațawwuruhā, 16.

${ }^{22}$ Iaitu menurut neraca mantik - secara umum - yang merujuk kepada "pemikiran yang tersusun-atur dan sistematik" sehingga ia berupaya memisahkan kebenaran daripada kesamaran yang mengkaburinya. Penyelarasan ini ditekankan oleh penjelasan al-Qur'ān dan bimbingan Muslimin yang benar dalam mengembangkan asasnya. Lihat Muhammad Sa'ìd Ramaḍān al-Būṭi, al-Salafiyyah: Marhalah Zamāniyyah Mubārakah Lā Madhhab Islāmiyy (Dimashq: Dār alFikr, 1998), 55 \& 229.

${ }^{23}$ Ibid., 229.

${ }^{24}$ Epistemologi ialah salah satu pokok perbincangan falsafah yang mengkaji tentang prinsip pengetahuan manusia, tabiat, punca, nilai dan batas cakupannya serta hubungan si penanggap dengan subjek yang ditanggapi. Ia berfungsi memecahkan persoalan mengenai perbezaan di antara pengetahuan yang benar dengan yang salah. Lihat al-Mu`jam al-Falsafi (Kaherah: Majma' al-Lughah al'Arabiyyah, 1979), 203. 
kebolehpercayaan sumber menerusi firman Allah SWT dalam ayat 6 , surah al-Hujurāt:

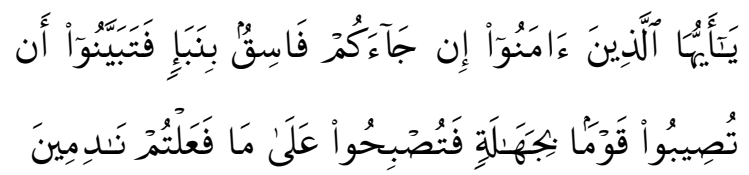

Terjemahan: Wahai orang-orang yang beriman, jika datang kepadamu orang fasik membawa suatu berita, maka periksalah dengan teliti, agar kamu tidak menimpakan suatu musibah kepada suatu kaum tanpa mengetahui keadaannya yang menyebabkan kamu menyesal atas perbuatanmu itu.

Juga, firmanNya dalam ayat 36, surah al-Isrā' berhubung aspek keautoritian dalil:

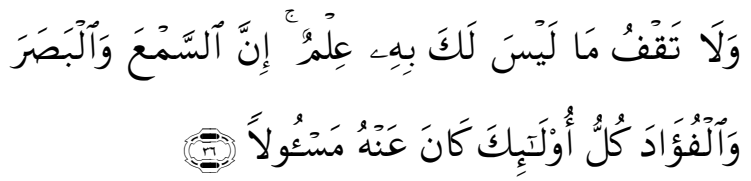

Maksudnya: Dan janganlah kamu mengikuti apa yang kamu tidak mempunyai pengetahuan tentangnya. Sesungguhnya pendengaran, penglihatan dan hati, semuanya itu akan diminta pertanggungjawabannya.

Penekanan al-Qur'ān berkenaan kepentingan metode dalam berinteraksi dengan sumber ilmu ini dirumuskan oleh Imam Abū al-Hasan al-Ash ’arī sebagaimana berikut:

$$
\begin{aligned}
& \text { حكم مسائل الشرع التي طريقها السمع أن تكون مردودة } \\
& \text { إلى أصول الشرع الذي طريقه السمع وحكم مسائل } \\
& \text { العقليات والمحسوسات أن يرد كل شيء من ذلك إلى بابه } \\
& \text { ولا يخلط العقليات بالسمعيات ولا السمعيات بالعقليات }
\end{aligned}
$$


Terjemahan: Hukum berhubung persoalan syarak yang jalan metodenya adalah melalui pendengaran - perkhabaran wahyu -, maka ia hendaklah dikembalikan kepada asal syarak yang bermetodekan wahyu; manakala hukum berhubung persoalan akliah dan inderawi, maka ia hendaklah dikembalikan kepada pintupintunya - metodologi-metodologinya -. Janganlah dicampur-adukkan di antara bidang urusan - akalan dengan wahyu dan juga di antara wahyu dengan akliah. ${ }^{25}$

Dalam erti kata lain, keilmiahan tafsiran dan kefahaman sesuatu bidang itu merujuk kepada kesesuaian manhaj atau metode yang serasi dengan tabiat sumber ambilan bidang tersebut. Islam mendukung usaha pemurnian setiap disiplin ilmu daripada pencemaran unsur-unsur asing yang menggugat nilai keneutralannya. ${ }^{26}$

Dalam konteks keautoritian wahyu - al-Qur'ān dan al-Hadīth - sebagai sumber kehidupan beragama, maka cara berinteraksi dengannya menuntut penggunaan metode periwayatan dan penafsiran nas yang muktabar. Kualiti ilmiah ini merupakan kekhususan manhaj Ahl al-Sunnah wa al-Jamā' ${ }^{27}{ }^{27}$ yang diungkapkan sebagai:

$$
\text { إن كنت ناقلا فالصحة ,وإن كنت مدعيا فالدليل }
$$

Terjemahan: Jika anda menyampaikan sebarang berita, maka pastikan kesahihannya

${ }^{25}$ Abū al-Hasan 'Alī al-Ash `arī, Risālah Istiḥsān al-Khawẹ fì 'Ilm alKalām (Beirut: Dār al-Mashāri', 1995), 47 \& 48.

${ }^{26}$ Muḥammad Sa `̄id Ramaḍān al-Būṭī, “Azmah al-Ma rifah wa 'Ilājuhā fî Hayātinā al-Fikriyyah al-Mu āșirah,” dalam al-Manhājiyyah alIslāmiyyah wa al- 'Ulūm al-Sulūkiyyah wa al-Tarbawiyyah (Virginia: al-Ma had al-'Ālami li al-Fikr al-Islāmī, 1990), 65 \& 66 dan Zulkifli Ismail, Ancaman Bahaya Sekularisme (Sungai Udang: Baitul Qurra', 2002), 32-38.

27 Al-Būṭī, al-Salafiyyah, 94 dan Sa id Hawwā, al-Asās fì al-Sunnah (jil. 1), 325. 
dan jika anda mendakwa sebarang kenyataan, maka pastikan pendalilannya. ${ }^{28}$

Melalui kombinasi dua kaedah utama ini, maka berkembanglah disiplin ilmu Islam yang mencermati aspek kebolehpercayaan sumber dan status periwayatan nas, juga disiplin ilmu yang menganalisis aspek pelaziman makna dan wajah pendalilan yang mendalam terhadap nas. ${ }^{29}$ Berdasarkan manhaj keilmuan yang luas ini, Imam 'Abd al-Qāhir al-Baghdādī telah merangkumkan lapan kelompok umat Islam sebagai keseluruhan golongan Ahl al-Sunnah wa al-Jamā’ah, termasuk mutakallimin Șifātiyyah, imam fiqah daripada ahli al-ra'yi dan ahli alhadìth, muhaddithīn, ${ }^{30}$ ahli nahu bahasa Arab, ulama qirā'at dan mufassirīn, ahli tasawwuf, mujāhidin di medan perang dan masyarakat awam yang mendukung syiar Ahl al-Sunnah itu sendiri. ${ }^{3}$

28 Muhammad Sa'īd Ramaḍān al-Būțī, Kubrā al-Yaqīniyyāt alKawniyyah: Wujūd al-Khāliq wa Wazīfah al-Makhlūq (Dimashq: Dār al-Fikr, 1990), 34 dan al-Farfūr, Muḥammad `Abd al-Lațīf Sāliḥ, Mi yār al-Ma āyir aw Ușūl al-Khilāf al-'Ilmō (Dimashq: Dār alMa'mūn li al-Turāth, 1988), 51.

29 Al-Būṭī, Kubrā al-Yaqīniyyāt al-Kawniyyah, 34-47 dan al-Būṭ̂̄, alSalafiyyah, 60-94.

30 Inilah antara polemik asas Ash`ariyyah dan Salafiyyah apabila terdapat kalangan Salafiyyah yang cuba membataskan Ahl al-Sunnah wa al-Jamā'ah sebagai al-țāifah al-manșūrah atau al-firqah alnäjiyah (golongan yang berjaya) kepada kelompok ahli al-Hadīth atau muhaddithin sahaja. Pandangan ini ditolak oleh ulama Ash`ariyyah seperti Sa '̄i Hawwā, Habīb al-Raḥman al-A`zamī dan al-Sayyid Muḥammad Ibrāhīm `Abd al-Bā’ith al-Kattānī. Menurut Ash ariyyah, muhaddithin hanya sekelompok Ahl al-Sunnah wa alJamā'ah, bukan keseluruhan Ahl al-Sunnah wa al-Jamā'ah itu sendiri. Lihat Sa id Hawwā, al-Asās fì al-Sunnah wa Fiqhuhā: al'Aqā'id al-Islāmiyyah (al-mujallad al-awwal) (Shāri al-Azhar: Dār al-Salam, 1992), 476 \& 477 dan al-Sayyid Muḥammad bin Ibrāhīm bin 'Abd al-Bā'ith al-Husayn̄̄ al-Kattān̄̄, Ibrā' al-Dhimmah bi Tahqūq al-Qawl hawl Iftirāq al-Ummah (al-Ghardaqah: Dār alSafwah, 1997), 37.

31 Al-Baghdādī, al-Farq bayn al-Firaq, 313-318. 
Sepanjang perkembangannya, risalah Șifātiyyah atau Ahl al-Sunnah telah didukung bersama oleh golongan alathariyyah (ahli al-Hadīth) yang berimamkan Ahmad bin Hanbal, al-Ash ariyyah yang berimamkan Abū al-Hasan al-Ash arī dan al-Māturīdiyyah yang berimamkan Abū Manșūr al-Māturīdī. ${ }^{32}$

\section{Manhaj Ahl al-Sunnah wa al-Jamā'ah}

Kepentingan manhaj Ahl al-Sunnah wa al-Jamā'ah dalam memelihara ketulenan ajaran Islam dan kemurnian akidahnya dapat ditinjau sepertimana perbahasan berikut:

\section{a. Manhaj berinteraksi dengan nas agama}

Makna keiltizaman terhadap al-Qur'ān dan al-Hadīth, juga makna penerimaan ajaran Islam sebagai suatu keyakinan dan amalan adalah merujuk kepada tiga proses berikut:

i. Memastikan kesahihan nas-nas yang warid dan dinukil daripada Rasulullah SAW, sama ada alQur'ān atau al-Hadīth sehingga tercapai keyakinan bahawa nas-nas itu bersumber daripada baginda dan bukan direka-reka;

ii. Meneliti makna yang terkandung dalam nas-nas itu secara halus sehingga tercapai ketenangan terhadap maksud si empunya nas-nas tersebut;

iii. Menimbang dapatan makna dan maksud yang telah diteliti dan dipastikan tadi menurut ukuran mantik (susun-atur) akal ${ }^{33}$ dengan tujuan saringan dan pemurnian berhubung asas kemunasabahannya.

${ }^{32}$ Lihat Hamād al-Sinān dan Fawzī al-`Anjariyy, Ahl al-Sunnah alAshā 'irah: Shahādah 'Ulamā' al-Ummah wa Adillatuhum (Kuwait: Dār al-Diyā', 2006), 87.

${ }^{33}$ Ia bermaksud kaedah dirāyah atau garis panduan ilmu secara umum, juga pemikiran yang tersusun atur dan sistematik sebagaimana yang ditemukan dalam sejarah pemikiran ulama Islam. Lihat perbahasan ini dalam Manāhij al-Bahth `ind Mufakkiri al-Islām, karya `Alī Sāmī al-Nashshār. 
Usaha mencapai semua tujuan ini memerlukan bantuan manhaj atau metode. ${ }^{34}$ Manhaj atau metode adalah "jalan yang dapat menjamin seseorang pengkaji untuk sampai kepada kebenaran yang dicari tanpa tersimpang atau tersasar daripadanya, juga tanpa terkeliru dengan kepalsuan yang disangkakannya sebagai kebenaran yang dicari itu". ${ }^{35}$

\section{Manhaj atau kaedah periwayatan nas}

Melalui langkah pertama, ulama al-Hadīth membahagikan khabar berita daripada baginda SAW kepada darjat mutawātir, ahād dan daîf. Secara aplikasi di bidang akidah, khabar mutawātir menjadi hujah mulzamah (mengikat) yang mengakibatkan terbatalnya akidah seseorang dan menjerumuskannya kepada kekufuran jika tidak mempercayainya secara jazam. Sebaliknya, khabar ahād tidak menjadi hujah sedemikian dalam erti kata jika ia tidak diyakini secara jazam, maka ia tidak mengakibatkan kekufuran tetapi menyebabkan kefasiqan. ${ }^{36}$ Ini kerana keyakinan yang jazam terhadap khabar ahād yang tidak mutawātir bererti memaksa akal di luar bebanannya untuk mempercayai sesuatu secara putus tanpa ruang kemampuan baginya.

Ini berbeza dengan bidang hukum amali seperti ibadat, muamalat dan seumpamanya di mana dalil yang zanniyy mewajibkan seseorang Muslim untuk berpegang dengannya, mengambil panduan daripadanya dan beriltizam dengan tuntutannya. ${ }^{37}$ Berhubung hadīth ḍa îf,

${ }^{34}$ Al-Būṭ̂i, al-Salafiyyah, 63.

35 Al-Būțī, al-Salafiyyah, 60 dan `Abd al-Mun `im Khafājī, al-Mu jam al-Falsafi (Kaherah: al-Dār al-Sharqiyyah, 1990), 340.

36 Termasuk dalam kategori ini adalah syafaat al-'Uẓmā baginda di Mahsyar, sepuluh sahabat yang masuk syurga, soalan munkar nakir dalam kubur, pelaku dosa besar tidak kekal dalam neraka dan sebagainya.

${ }^{37}$ Mengenai isu sama ada Hadīth Ahād berkedudukan memberi faedah zann atau ilmu berhubung akidah, lihat perbahasan lanjut oleh Yusūf 
terdapat pelbagai jenis - matrūk, mursal, maqț̄̄ dan sebagainya - yang kesemuanya tidak diambil-kira di bidang akidah hukum perlakuan. Namun menurut kebanyakan ulama, hadīth ḍaif harus diamalkan berhubung perkara fadā' il dengan syarat ia tidak sampai ke taraf yang tersangat $d a ` i f$, manakala perawinya tidak mengiktikadkan kesahihannya - sebagai benar-benar bersumber daripada baginda SAW -. ${ }^{38}$

\section{Manhaj atau kaedah penafsiran nas}

Dalam berinteraksi dengan nas agama, ulama menentukan garis panduan dalam ilmu Ușūl al-Tafsīr atau Manāhij alMufassirīn. Dalam menggandingkan aspek periwayatan (tafsìr al-riwāyah atau bi al-ma'thur) dan aspek kemahiran ilmu atau kefahaman (tafsīr al-dirāyah atau bi $\left.a l-r a^{\prime} y\right)$, tafsir al-Qur'ān dengan al-Qur'ān didahulukan, kemudian dituruti oleh tafsir al-Qur'ān dengan al-Sunnah dan disusuli pengutamaan terhadap tafsir al-Qur'ān dengan kata-kata sahabat dan tabiin. Setelah itu, terdapat juga metode penafsiran al-Qur'ān dengan pandangan akal yang terkawal berpandukan kaedah dan syarat kelayakan seperti yang dibahaskan oleh ulama di bidang ini. ${ }^{39}$

Berhubung keilmiahan manhaj Ahl al-Sunnah, setelah nas-nas dipastikan kesahihan periwayatannya, maka disusuli pula usaha menghasilkan aspek dirāyah yang sempurna dan sahih. Di tahap ini, timbul punca perselisihan pendapat yang bercabang-cabang berhubung ijtihad dan fatwa fiqah serta persoalan akidah, lantaran ketiadaan neraca yang disepakati oleh ulama ke atasnya dalam memahami nas dan menentukan penunjukan maknanya.

al-Qarādawī, al-Sunnah Mașdaran li al-Ma`rifah wa al-Haḍārah (Kaherah: Dār al-Shurūq, 1998), 94-98.

${ }^{38}$ Al-Būṭ̂̄, al-Salafiyyah, 65-68.

39 Lihat al-Tafsīr wa al-Mufassirūn karya Muhammad Husayn alDhahabī dan al-Marji iyyah al- ‘ulyā fì al-Islām li al-Qur'ān wa alSunnah karya Yusūf al-Qarādawī. 
Namun, neraca ini berjaya disingkap dan dibukukan oleh para ulama dalam struktur manhaj yang lengkap tentang agama dan hukum-hakam akidah serta perlakuan. Secara ilmiahnya, panduan Islam tidak tercapai kecuali melalui sandaran kepada nas atau sesuatu yang setaraf kekuatan dengan nas dan tuntutan pelazimannya seperti mengambil dalil (istidlāl) dan melakukan qiyās ke atasnya. Hakikat Islam tidak bersandar kepada pandangan - atau spekulasi akal - semata-mata - yang bebas daripada sebarang pergantungan. Inilah perbezaan Islam dengan agama dan ideologi lainnya. ${ }^{40}$

Setelah dikenal pasti kedudukan nas tersebut, maka langkah berikutnya menuntut penelitian lafaz dan susunan ayatnya berhubung makna yang dikehendaki secara sahih, juga dengan berpandukan al-Sunnah sebagai rincian keterangan bagi syariatNya. Manhaj ini merujuk kepada kaedah tatabahasa Arab dan panduan kefahaman lafaz Arab serta struktur susunannya yang diperakui dalam menafsirkan nas.

Ulama Ahl al-Sunnah telah menyusun kaedah penafsiran nas ini melalui disiplin ilmu yang membincangkan tentang al-dilālāt (penunjukan) iaitu prinsip penunjukan lafaz terhadap makna dan al-bayān (penjelasan) yang menangani gambaran kontradik antara sesama pernyataan dan cara menyelaraskannya. Ini termasuk perbahasan takwil dan menyingkap kekaburan sesuatu perkataan atau ayat. Melalui manhaj ini penafsiran yang sahih terhadap nas agama dapat dibezakan dengan penafsiran yang palsu oleh pendukung hawa nafsu dan ahli bidaah. ${ }^{41}$

\footnotetext{
${ }^{40}$ Ibid., 70.

${ }^{41}$ Ibid., 72-79.
} 


\section{Manhaj berhubung piawaian intipati ajaran Islam}

Kesatuan umat Islam adalah berpaksikan pegangan yang teguh kepada al-Kitab dan al-Sunnah. Setia kepada ajaran baginda SAW bererti komitmen dan amanah berhubung pendekatan yang sah dan ilmiah dalam berinteraksi dengan kedua-dua sumber induk tersebut melalui manhaj periwayatan dan penafsiran nas. Natijah daripada aplikasi manhaj tersebut, maka terbentuklah piawaian intipati ajaran Islam seperti berikut:

i. Persoalan yang berupa ma'lūm min al-dìn bi aldarūrah;

ii. Persoalan yang putus (qați) secara kesabitan dan penunjukannya;

iii. Persoalan yang putus secara kesabitannya tetapi zanniyy penunjukannya;

iv. Persoalan yang zanniyy secara kesabitan dan penunjukannya;

v. Persoalan yang zanniyy secara kesabitannya tetapi putus penunjukannya. ${ }^{42}$

\section{i. Persoalan ma 'lūm min al-dīn bi al-darūrah}

Persoalan ma 'īm min al-dīn bi al-ḍaūrah merujuk kepada ilmu yang dimaklumi oleh umum umat Islam yang berfikiran waras tanpa mengambil-kira tahap keilmuan mereka. Tiada keuzuran bagi mereka dalam menjahilinya, lantaran ia wujud secara nas al-Qur'ān dan diketahui oleh masyarakat awam yang disampaikan oleh kalangan awam

${ }^{42}$ Lihat Sa`id Hawwā, al-Asās fìal-Sunnah wa Fiqahuhā: al-`Aqā’id alIslāmiyyah (al-mujallad al-awwal) (Shāri` al-Azhar: Dār al-Salām, 1992), 325 dan 'Abd al-`Aẓim al-Maț an̄̄, Hadhā Bayān li al-Nās: al-Shubuhāt al-Thalathūn al-Mathārah li Inkār al-Sunnah alNabawiyyah (Kaherah: Maktabah Wahbah, 1999), 120 dan Anwār al-Jundī, Naḥw Binā' Manhaj al-Badā'il al-Islāmiyyah (Kaherah: Dār al-Г tișām, t.th.), 152. 
sebelumnya seperti yang dikhabarkan oleh Rasulullah SAW tanpa diperselisihkan. ${ }^{43}$

Ini termasuk persoalan mengenai asas akidah seperti kewujudan Allah SWT, keesaan dan kesempurnaan sifat ketuhananNya, kerasulan Nabi Muhammad SAW dengan risalah dan wahyu terakhir baginda, perihal kebangkitan semula dan pembalasan hari akhirat serta malaikat yang setia mematuhi perintahNya, ${ }^{44}$ juga merangkumi hukumhakam Islam yang pokok seperti kefarduan rukun Islam yang lima, keharaman riba, zina, membunuh, mencuri dan minum arak. ${ }^{45}$ Pengingkaran terhadap perkara yang diijmakkan tetapi tidak berstatus ma 'lüm min al-dìn bi aldarūrah tidaklah mengimplikasikan kekufuran. ${ }^{46}$

Maksud al-Hadīth tentang ancaman neraka bagi pelaku bidaah dan sesat adalah keadaan mereka layak (mustahiq) untuk masuk ke dalam neraka disebabkan iktikad mereka, bukan bermakna mereka pasti benar-benar memasukinya secara realiti (bi al-fi l). Ahl al-Sunnah

43 Namun, kejahilan seorang Muslim terhadap perkara yang menyebabkan kekufuran tidak menguzurkannya daripada terjerumus ke dalam kekufuran kerana ia disebabkan oleh kecuaiannya terhadap agama. Contohnya, seorang yang jahil bahawa mencerca Allah SWT adalah kufur, lantas ia mencercaNya. Ini tidak dianggap suatu pelepasan untuk ia tidak dihukumkan kufur di atas alasan ia menjahilinya. Inilah pandangan ulama Mālikiyyah seperti al-Qāḍ̄ 'Iyāọ dan ulama Shāfi 'iyyah seperti Ibn Hajar, juga ulama Hanafiyyah. Berhubung pengingkaran terhadap perkara yang ma ' $\bar{u} m$ min al-dīn bi al-darūrah pula, jika ia tidak mengetahuinya sebagai ma `ūm min al-dīn bi al-ḍaürah, maka ia tidak dihukumkan kufur. Bahkan, ia perlu diajar mengenai kedudukan perkara tersebut. Jika ia mengulanginya setelah itu, maka barulah ia dianggap kufur. Pengecualian ini termasuklah bagi mereka yang baru memeluk Islam (qarīb ‘ahd bi Islām) dan menjahilinya sebelum masuk Islam. Lihat 'Abd Allāh al-Hararī, al-Sharḥ al-Qawīm fi Hall Alfāz al-Ṣirāt alMustaqīm (Beirut: Dār al-Mashārī', 1999), 283 \& 284.

${ }^{44}$ Al-Qarādawī, al-Sunnah, 94 \& 95.

${ }^{4}$ Al-Būṭì, al-Salafiyyah, 73.

${ }^{46}$ Aḥmad bin Muhammad al-Sāwī, Sharh al-Sāwi ‘alā Jawharah alTawhīd (Dimashq: Dār Ibn Kathīr, 2005), 423 \& 424. 
berpandangan bahawa harus sahaja mereka tidak masuk neraka disebabkan keampunan Allah SWT atau disebabkan syafaat tertentu selama mana iktikad mereka tidak membawa kepada kekufuran. Sebaliknya, jika ia mewajibkan kekufuran, maka ia terkeluar daripada kumpulan Islam dan kekal dalam neraka.

Mukmin yang melakukan bidaah iktikad pula masuk ke dalam neraka tanpa kekal, bahkan bertempoh. Ini berbeza dengan ahli falsafah yang mengiktikadkan kekadiman alam, mengingkari akhirat, pengutusan rasul dan kebanyakan asas agama, juga naturalis yang menyandarkan segala sesuatu kepada tabiat semula jadi dan mengingkari al-Fāil al-Mukhtār (Tuhan sebagai Pelaku yang bebas), semuanya dianggap terkeluar dari kumpulan Islam. Ini kerana keingkaran mereka terhadap kebanyakan kepastian (darūriyyāt $)$ agama. ${ }^{47}$

Asas kekufuran melibatkan berlakunya pendustaan (takdhīb) terhadap apa yang dikhabarkan oleh Rasulullah SAW atau keengganan mengikuti baginda berserta ilmu tentang kebenarannya. Pendustaan tersebut pula berlaku terhadap: i) nas yang sabit dengan ijmak yang qat ‘yy dan mutawātir bahawa ia dinyatakan oleh baginda, ii) makna yang sabit dengan ijmak yang qat iyy dan mutawātir bahawa baginda menghendaki atau memaksudkannya. ${ }^{48}$ Sebarang pendustaan pasti mewajibkan pengkafiran sekalipun dalam perkara cabang.

Contohnya, sesiapa yang mendakwa bahawa Baitullah di Mekah bukan Ka`bah yang diperintahkan oleh Allah bagi ibadat haji, maka ia menjadi kafir kerana apa yang sebaliknya adalah sabit secara mutawatir daripada baginda. Demikian juga sesiapa yang menisbahkan kekejian terhadap Saidatina Aishah RA, sedangkan turun ayat al-Qur'ān yang membersihkannya, maka ia menjadi

\footnotetext{
${ }^{47}$ Muhammad Wahbī, al- 'Aqā'id al-Khayriyyah, 6 \& 7.

${ }^{48}$ Sa’d al-Dīn bin Muhammad al-Kūbī, Dawābit al-takfìr ind Ahl alSunnah wa al-Jamā 'ah (Beirut: al-Maktab al-Islāmī,1997), 20 \& 21.
} 
kafir kerana menyalahi mutawatir. Berbeza dengan pengingkaran apa yang sabit dengan khabar aḥād yang tidak melazimkan kekufuran, manakala pengingkaran terhadap apa yang sabit secara ijmak, maka ia memerlukan perincian lanjut. ${ }^{49}$

Secara lebih terperinci, tahap pendustaan tersebut dikategorikan - oleh al-Ghazalī - menurut beberapa golongan berikut iaitu:

- Pendustaan Yahudi, Nasrani, Majusi dan penyembah berhala yang dinaskan kekufurannya dalam al-Qur'ān sebagai induk bagi golongan lainnya;

- Pendustaan penganut Brahmin yang mengingkari asas kenabian, juga golongan Dahriyy atau ateis yang mengingkari Pencipta alam;

- Ahli falsafah yang mempercayai Tuhan Pencipta dan nabi tetapi mengiktikadkan perkara yang menyalahi nas-nas syarak. Meskipun mereka memperakui kebenaran nabi, namun tiga pendapat mereka ini wajib dihukum kufur secara putus iaitu: a) pengingkaran terhadap kebangkitan jasad dan penyiksaannya secara fizikal dalam neraka serta kelazatan fizikal dalam syurga; b) dakwaan bahawa Allah tidak berilmu secara terperinci tentang segala yang baharu, sebaliknya hanya mengetahui secara umum; c) dakwaan bahawa alam adalah kadim, manakala terdahulunya Allah daripada alam adalah seumpama terdahulunya ‘illah daripada ma ' $\bar{u} l$ nya. Mereka mengetahui ketetapan syarak secara putus bahawa mendustakan baginda SAW membawa kekufuran, namun mereka tetap mendustainya dengan alasan yang palsu;

49 al-Ghazāī̄, Abū Hāmid Muḥammad bin Muḥammad, Fayṣal alTafrīqah bayn al-Islām wa al-Zanādiqah (Beirut: Dar al-Fikr alLubnani, 1993), 74. 
- Mu`tazilah, Mushabbihah dan golongan selain ahli falsafah yang membenarkan nabi dan tidak berdusta demi mașlahat palsu yang tertentu, namun tersilap dalam melakukan takwil dan ijtihad mereka,

- Mereka yang tidak berdusta secara nyata tetapi tetap mengingkari asas syarak yang dimaklumi secara mutawātir daripada Rasulullah SAW seperti kata-kata bahawa solat lima waktu tidak wajib atau meragui lokasi Mekah dan Ka`bah bagi kefarduan haji. Namun, jika pendustaan itu tidak melibatkan pokok agama seperti peperangan yang disertai baginda SAW atau pernikahannya dengan Saidatina Hafsah, maka ia tidak melazimkan pengkafiran,

- Mereka yang tidak berterus-terang mendustakan perkara ma lūm min al-dīn bi al-ḍarūrah dan mutawātir daripada pokok agama tetapi mengingkari apa yang diketahui kesahihannya melalui ijmak dalam memahami nas agama. ${ }^{50}$

Manhaj akidah Ahl al-Sunnah wa al-Jamā’ah penting demi melindungi umat Islam daripada ancaman akidah dan anasir yang merosakkannya seperti gejala kufur, syirik, riddah, bidaah, fasiq, nifaq serta ciri-cirinya. ${ }^{5}$ Namun, Ahl al-Sunnah tidak mudah mengkafirkan mereka yang dianggap pelaku bidaah sehingga dianggap keluar Islam. Sekalipun berlaku penolakan terhadap sebahagian hadīth yang mutawātir atau masyhur, apa yang diputuskan dengan tegas adalah status kebidaahan mereka. Status

${ }^{50}$ Abū Hāmid Muhammad bin Muhammad al-Ghazālī, al-Iqtișād fí alI'tiqād (Beirut: Dār al-Kutub al-'Ilmiyyah, 2004), 134-137.

${ }^{51}$ Lihat al-Fạdil Umar bin Zayn al-' Ābidīn Fațānī, "Asbāb al-Murtad", dalam Majmū ’ah al-Tawhīd (Miṣr: Mușțafā al-Bābī al-Ḥalabī, 1936), 9-12, Mustika al-Hadīth (jil. dua) (Kuala Lumpur: Majlis Kebangsaan Hal Ehwal Agama Islam, Jabatan Perdana Menteri, 1984), 254-257 dan Sa īd Hawwā, al-Islām ('Amman: Dār `Ammār, 1988), 76-94. 
kekufuran mereka yang mengingkari hadīth mutawātir tidak termasuk dalam perkara yang diputuskan secara ijmak. Apa yang diijmakkan kekufurannya hanyalah jika berlaku pengingkaran berhubung perkara ma 'üm min aldìn bi al-darürah. Persoalan agama yang bersatatus zanniyy tidak dihukumkan kafir bagi sesiapa yang mengingkarinya, sekalipun ia termasuk dalam perbuatan bidaah yang menyimpang dari mazhab salaf dan Ahl alSunnah wa al-Jamā’ah. ${ }^{52}$

Pengajian akidah perlu bermatlamat menyelamatkan akidah umat Islam dengan penjelasan mengenai batasbatas iman dan kufur menurut adab dan hikmah dalam berdakwah tanpa menuduh sesiapa secara khusus. Di antara panduan asas berkaitan adalah: i) dua kalimah syahadah adalah pintu masuk Islam, ii) sesiapa yang mati dalam tauhid layak terpelihara daripada kekal dalam neraka dan layak memasuki syurga, iii) seorang Muslim wajib beriltizam dengan ajaran Islam, iv) maksiat mengurangkan iman tanpa menafikannya secara keseluruhan, v) syirik adalah dosa yang tidak diampunkan oleh Allah SWT, vi) kufur yang kecil - lawan bagi syukur - adalah dosa yang diancam siksaan neraka tanpa kekal di dalamnya, manakala kufur yang besar - lawan bagi iman adalah pendustaan terhadap apa yang datang bersamasama Rasulullah SAW, lantas mengeluarkan seseorang daripada Islam berhubung hukum di dunia dan melayakkannya kekal dalam neraka di akhirat, vii) adakalanya, iman seseorang di'tempiasi' unsur kekufuran, Jahiliyyah atau kemunafikan - yang menengahi status Mukmin dan Kafir -, viii) martabat keimanan manusia ditentukan menurut hubung-kaitnya dengan arahan dan larangan Allah SWT. ${ }^{53}$ Panduan asas ini memerlukan huraian ilmiah yang lebih lanjut.

\footnotetext{
52 Al-Qaradāwī, al-Sunnah, 96 \&97.

${ }^{53}$ Yusūf al-Qaraḍāwī, Hudā al-Islām: Fatāwā Mu āsarah (Kuwait: Dār al-Qalam, 1990), 121-151.
} 


\section{b. Autoriti ijmak dan persoalan zanniyy akidah yang diijtihadkan}

Setiap permasalahan syarak yang tidak mempunyai dalil qat iyy dari aspek kesabitan dan penunjukannya - sama ada persoalan asas iktikad atau cabang amali - merupakan keluasan medan ijtihad. Kedatangan syarak dalam bentuk zanniyy tersebut menjadi dalil keizinan untuk berijtihad di dalamnya. Jika tidak, nescaya Allah SWT menjadikannya sebagai dalil qaț ìyy dan nas muhkamāt tanpa perlu tilikan atau pemerhatian akal. Hikmahnya adalah meluaskan kefahaman dan tafsiran yang sekalipun saling salahmenyalahkan tetapi tidak sampai ke tahap saling mengkafirkan di antara satu sama lain.

Justeru, pembahagian kepada kategori - atau 'label' perkara asas yang mengakibatkan kekufuran jika diingkari dengan kategori - atau 'label' - perkara cabang yang tidak mengakibatkan kekufuran jika diingkari adalah 'rapuh' dan hanya akan menatijahkan gejala mengkafirkan (takfir) kepada lawan masing-masing - seperti yang menimpa Mu`tazilah -. Ini kerana pandangan satu-satu pihak yang didakwa melibatkan perkara asas yang bukan berstatus ijtihad, lantas menuduh pihak saingannya sebagai kufur pasti akan menyeret pihak saingannya itu untuk menuduh pula pihak tersebut sebagai kufur sedang gejala takfir adalah berisiko untuk diceburi oleh seorang Muslim yang celik. $^{54}$

Kalangan ulama ușüliyy telah membahaskan secara khusus berhubung kedudukan ijtihad dalam persoalan iktikad ini. Menurut al-Ghazālī dan al-Taftāzānī, ijtihad berhubung persoalan al- aqliyyāt iaitu perkara yang dapat ditanggapi oleh akal dan tidak bergantung kesabitannya dengan dalil sam iyy, - namun tidak dinafikan bahawa ia turut sama ditunjukkan oleh dalil sam iyy tersebut seumpama kebaharuan alam, kewujudan Allah SWT

\footnotetext{
${ }^{54}$ Yūsuf al-Qaraḍāwī, al-Ijtihād fì al-Sharī’ah al-Islāmiyyah (Kuwait: Dār al-Qalam, 1996), 65-67.
} 
berserta sifatNya dan pengutusan rasul adalah pasti memiliki sisi kebenaran dan sisi kesilapannya. Pihak yang benar berhubung persoalan itu adalah satu, maka sesiapa yang ijtihadnya menyepakati kenyataan adalah diganjari, manakala pihak yang tersilap pula dianggap berdosa sekalipun ia bersungguh-sungguh dalam ijtihad dan pengamatannya.

Alasannya, dalil akal yang qat ïyy lagi tersusun daripada premis hujah (muqaddimāt) yang darūriyy atau tersusun daripada muqaddimāt teoritikal yang berkesudahan dengan muqaddimāt yang ḍarūriyy menghasilkan natijah iktikad yang qat ïyy dan jazam serta menepati kenyataan - tanpa tanggungan terhadap lawannya, lantas sisi benar bagi mujtahid tersebut adalah satu sahaja. ${ }^{55}$

Justeru, jika kesilapan tersebut melibatkan keimanan kepada Allah SWT dan rasulNya, maka ia menjadi kafir. Sebaliknya jika tidak melibatkan asas keimanan atau menafikan agama, maka ia hanya berdosa dan melakukan bidaah - seperti isu melihat Allah SWT di akhirat dan isu kemakhlukan al-Qur'ān - tanpa melazimkan kekufuran. ${ }^{56}$ Inilah contoh ijtihad Muktazilah yang dianggap berdosa akibat sesat dan menyimpang dari kebenaran, tersilap akibat menyalahi kebenaran yang meyakinkan serta berbuat bidaah akibat menyalahi apa yang masyhur di kalangan generasi salaf. Namun, mereka tetap tidak dianggap kafir dengan makna iktikad dan hakiki. ${ }^{57}$ Contoh lain ialah:

55 Sebaliknya, jika diandaikan bahawa kedua-dua mujtahid yang berlawanan pandangan tadi sebagai betul - dengan sandaran dalil akal yang menepati hakikat kenyataan tadi -, maka ini bercanggah dengan hukum akal yang pasti. Termasuk di kalangan mereka yang mendukung perspektif 'paradoks' ini ialah al-Jāḥiz dan al-'Anbarī dari Mu`tazilah yang disanggah oleh al-Ghazālī dalam al-Mustaşā̄.

56 Jalāl al-Dān 'Abd al-Raḥman, al-Ijtihād: Dawābițhu wa Aḥkāmuh (t.tp.: t.pt., 1986), 141-144.

${ }^{57}$ Ibid., 149. 
i. Berhubung persoalan sifat Allah: Mu`tazilah tidak dianggap kafir tetapi fasiq dan mubtadi dengan pengingkaran mereka terhadap sifat $m a^{`} \bar{a} n \bar{\imath}$ - seperti kudrat (pekuasa) -, sebaliknya mereka mengatakan bahawa Allah SWT berkuasa dengan ZatNya, bukan dengan sifat kudrat yang ada di ZatNya -. Ini berbeza jika berlaku pengingkaran terhadap sifat nafsiyyah - iaitu wujud -, sifat salbiyyah - yang lima - atau mensabitkan lawan bagi sifat ma ānī, maka ia menjadi kufur, ${ }^{58}$

ii. Berhubung keimanan kepada malaikat yang tidak berjantina: Sesiapa yang menyifatkan malaikat dengan kelelakian adalah fasiq, lantaran ia mendakwa sesuatu tanpa sandaran dalil tentang perkara ghaib. Namun sesiapa yang menyifatkan malaikat sebagai perempuan, maka ia jatuh kafir kerana pandangan ini bertentangan dengan firman Allah SWT dalam surah al-Zukhruf, ayat $19,{ }^{59}$

iii. Berhubung alam barzakh: Sesiapa yang mengingkari azab kubur adalah kufur, lantaran ia sabit dengan firman Allah SWT dalam surah Ghāfir, ayat 46, manakala sesiapa yang mengingkari soal jawab kubur tidak kafir, bahkan dihukum fasiq. Namun, pengingkaran tersebut tetap membawa kekufuran jika ia berbentuk perbantahan (al-`inād) seumpama ia mendengar bahawa baginda SAW mensabitkannya tetapi ia tetap mengingkarinya. ${ }^{60}$

iv. Berhubung peristiwa Isra' dan Mi'rāj: Sesiapa yang mengingkari berlakunya Isrā' adalah kufur, lantaran ia mendustakan al-Qur'ān (surah al-Isrā', ayat 1).

${ }^{58}$ Aḥmad bin Muḥammad Zayn bin Mușțafā bin Muḥammad al-Fatān̄̄, Farīdah al-Farā'id fì 'Ilm al-'Aqū'id (Pulau Pinang: Persama, 1951), 17.

${ }^{59}$ Muḥammad Rabī` Muḥammad Jawharī, ‘Aqūdatunā (Juž u al-Thān̄ī) (t.pt.: t.p., 2007), 6.

${ }^{60}$ Al-Hararī, al-Sharh al-Qawìm, 336 \& 337. 
Peristiwa Isrā' dari Masjid al-Harām ke Masjid alAqșā sabit dengan al-Qur'ān, al-Sunnah dan ijmak Muslimin. Sesiapa yang mengingkari berlakunya Mìrāj dari Masjid al-Aqșā ke langit ketujuh, syurga dan sempadan berikutnya pula, maka ia tidak kafir tetapi fasiq dan ahli bidaah (mubtadi), lantaran ia hanya sabit dengan khabar ahäd atau hadīth yang masyhur. ${ }^{61}$ Peristiwa Mìrāj tidak disebutkan dengan nas nyata yang tidak menanggung pentakwilan, bahkan ia hanya diisyaratkan bukan secara nas yang nyata dalam surah al-Najm, ayat 1315). ${ }^{62}$

Walau bagaimanapun, sumber ijmak tetap memiliki keautoritiannya yang tersendiri. Sebagai ijtihad bersama dan kolektif, ijmak ulama memiliki kehujahan qat iyy yang diwajibkan beramal dengannya, bahkan diharamkan menyalahinya serta dihukumkan kufur bagi sesiapa yang mengingkari atau mempertikaikan keasalan dan kehujahannya. ${ }^{63}$ Ulama berselisih mengenai kekuatan hujah ijmak, sama ada berstatus qat iyy atau zanniyy.

Menurut pendapat masyhur kebanyakan ulama, ijmak yang sampai melalui jalan mutawatir adalah qat iyy, lantas mengimplikasikan kekufuran atau kesesatan dan bidaah jika menyalahinya. Sebaliknya, ijmak yang sampai melalui jalan ahâad atau ijmak sukūti adalah zannìyy. Menurut ulama ușūliyy seperti al-Āmid̄̄, al-Isnawī dan Ibn al-Hajib, jika ijmak yang qat ‘yy itu masyhur di kalangan masyarakat awam seperti ibadat - rukun - yang lima, maka penafian atau penolakannya mengakibatkan kekufuran; jika tidak demikian, maka ia tidak kafir. Anggapan bahawa pengingkaran terhadap hukum ijmak

\footnotetext{
${ }^{61}$ Al-Sāwī, Sharh al-Sāwi, 312. Juga, lihat bait al-Jawharah ke-74.

${ }^{62}$ Al-Hararī, al-Sharh al-Qawìm, 310.

63 Wahbah al-Zuhaylī, Ușūl al-Fiqh al-Islāmì (al-juz'u al-awwal) (Dimashq: Dār al-Fikr, 1986), 538.
} 
menjadi kafir belum lagi sahih, bahkan perlu diperincikan betapa pengingkaran yang membawa kekafiran adalah melibatkan ijmak sahabat yang mutawātir, lantas kehujahannya dianggap qat iyy. Umpamanya, sesiapa yang tahu bahawa ketentuan rakaat sembahyang menjadi ijmak umum, namun tetap disanggahi, maka ia dihukum kafir. Sebaliknya, pengingkaran terhadap ijmak yang zanniyy tidak menjadi kafir.

Berikut adalah iktikad Ahl al-Sunnah wa al-Jamā’ah yang sekaligus merupakan prinsip agama yang tidak wajar diperselisihkan oleh umat Islam dalam menerimanya:

i. Islam adalah agama yang diperintahkan oleh Allah SWT untuk diikuti dan dipegang dengan teguh. Seluruh ajaran iktikad, fiqah dan adabnya bersumberkan al-Kitāb dan al-Sunnah serta apa yang sah daripada generasi sahabat, tabiin dan ijmak ulama.

ii. Allah SWT adalah esa pada Zat, sifat dan perbuatanNya. Tiada Pencipta, pemberi mudarat dan manfaat selainNya. Apa yang dinamakan sebagai 'sebab' hanya dicipta oleh Allah SWT menurut kemahuanNya semata-mata.

iii. Sifat ma $\bar{a}^{n} \bar{\imath} \overline{\mathrm{A}}$ Allah SWT iaitu kudrat, iradat, ilmu, hayat, sama', bașar dan kalam adalah sabit tanpa terpisah bagiNya. Semua sifat ini adalah kadim sebagaimana ZatNya. Kalam adalah sifatNya yang kadim lagi bukan makhluk.

iv. Tiada persamaan dan penyerupaan bagi Allah SWT dengan segala sesuatu pada zat, sifat dan perbuatanNya. Apa sahaja yang disifat dan dikhabarkan bagi zatNya dengannya - yang melazimkan penyerupaan dan penjisiman -, maka disabitkan bagiNya beserta penyucianNya daripada makna - penyerupaan dan penjisiman.

${ }^{64}$ Ibid., 549-551. 
v. Segala sesuatu adalah ciptaan Allah SWT sematamata. Kebaikan, keburukan dan perbuatan manusia dijadikan dengan kemahuan dan ciptaanNya. Selain daripada Allah SWT adalah baharu dan makhluk yang tidak muncul melainkan mempunyai permulaan.

vi. Segala kejadian berlaku dengan qada' dan qadar Allah SWT. Hidayah bagi Mukmin adalah dengan taufik dan belaian santunanNya. Kesesatan mereka yang ingkar adalah dengan penyesatan daripadaNya. Semua hamba diberikan kebebasan berikhtiar dan berusaha. Inilah makna keadilanNya.

vii. Ahli kiblat yang memenuhi ciri iman dan Islam pada fikiran dan hati tidak dihukum kafir dengan sebab berbuat dosa besar atau kecil. Jika keharamannya diketahui secara pasti dan dilakukan dengan menghalalkannya, maka ia menjadi kafir, manakala jika ia dilakukan dengan diyakini keharamannya, maka ia adalah fasiq.

viii. Allah SWT dapat dilihat pada hari kiamat dengan mata kasar sebagaimana bulan penuh dapat dilihat pada malam hari. Mukmin yang mati dengan kesudahan yang baik dapat melihatNya, manakala Kafir yang mati dengan kekufuran terhijab daripada melihatNya. Melihat Allah SWT tidak melazimkan sebarang kaifiat atau arah.

ix. Soalan dua malaikat, azab dan nikmat kubur adalah sabit dengan hadis sahih yang mutawātir ma nawī. Begitu juga kebangkitan semula jasad dan roh selepas mati, hisab, mīzān, titian șirāt dan kekalnya penghuni dalam syurga dan neraka. Mukmin yang melakukan maksiat diazab, kemudian dikeluarkan dari neraka. Syafaat yang dikurniakan dengan izin Allah SWT adalah sabit.

x. Kecintaan kepada generasi salaf pilihan Allah SWT yang mendampingi Rasulullah SAW adalah dituntut. 
Begitu juga mereka yang disaksikan sendiri kelebihan mereka oleh baginda. Beriktikad tentang tahap dan tertib urutan kelebihan mereka juga dituntut tanpa menceburi perselisihan yang berlaku dalam kalangan mereka.

xi. Agama menuntut umat Islam bersatu di atas prinsip hidayah. Wajib bagi mereka untuk berusaha mengikut segala arahan dan syariat Allah SWT, termasuklah menghidupkan syiar ibadat, juga mendoakan dan menasihati pemimpin dengan asas menyeru yang makruf dan mencegah yang mungkar.

xii. Alamat kiamat yang dikhabarkan oleh al-Qur'ān dan hadīth seperti keluarnya Dajjal, turunnya Nabi 'Īsā AS, Ya'jūj dan Ma'jūj, muncul binatang dari perut bumi. Yakin bahawa Nabi 'Îsā AS belum wafat atau dibunuh. Baginda akan turun semula ke bumi dengan hukum al-Qur'ān dan al-Sunnah, mematahkan salib, membunuh khinzir dan membawa panji perpaduan.

xiii. Bidaah dalam agama Allah bererti merekacipta atau mengada-adakan apa yang tiada kaitan dengan sebarang panduan dan sandaran kepada ajaran agama, sama ada berbentuk iktikad kefahaman atau ibadat. Jalan hidup beragama adalah 'mengikut' (ittiba '), manakala urusan kehidupan merujuk kepada maslahat.

xiv. Imam mazhab fiqah yang empat telah terbukti dapat menghimpunkan umat Islam melalui keluasan upaya dan ketinggian ilmu serta usaha ijtihad mereka berhubung hukum dan syariat Islam.

xv. Usaha mendapatkan ilmu dengan segenap disiplin dan cabangnya amat digesa oleh syariat kecuali ilmu sihir yang diijmakkan keharaman mempelajarinya, manakala mantik Yunani dan falsafah adalah diperselisihkan kadar dan aspeknya oleh ulama.

xvi. Kehidupan beragama yang dituntut dan ditaklifkan oleh Allah SWT ke atas hambaNya terdiri daripada 
iman, Islam dan ihsan yang saling berlaziman serta diambil panduannya daripada ilmu tauhid, ilmu fiqah dan ilmu tasawuf. ${ }^{65}$

Asas akidah ini perlu diambil-kira dalam mengenal pasti penyerapan fahaman asing. Jika timbul pertikaian terhadap sebarang prinsip tersebut, kemungkinan besar terdapat pengaruh bidaah iktikad yang berpunca daripada sistem kepercayaan yang tidak muktabar, lantas perlu diwaspadai dengan panduan ilmu dan bimbingan ulama.

Kesimpulannya, manhaj Ahl al-Sunnah juga penting dalam menangani isu perpecahan di kalangan umat Islam. Perselisihan pendapat wajar ditangani dengan mengenalpasti statusnya dengan mengambil kira prioriti yang lebih utama:

i. Pengingkaran terhadap perkara ma ' $\bar{u} m$ min al-dīn bi al-darūrah iaitu persoalan asas yang mengakibatkan seseorang itu kufur atau murtad;

ii. Perselisihan pendukung hawa nafsu yang menyalahi nas qat iyy pada kesabitan dan penunjukannya menurut ijmak, lantas menatijahkan kesesatan dan bidaah;

iii. Perselisihan dalam persoalan yang tidak wajar diperselisihkan, lantaran ia terkeluar dari kefahaman sahih menurut baginda SAW dan para sahabat, maka ia tidak dikufurkan tetapi tetap dihukumkan sesat, manakala kesesatan mempunyai peringkatperingkatnya;

iv. Perselisihan dalam persoalan yang wajar mengandungi perselisihan dan tidak mungkin dapat dielak atau dihapuskan. Selama mana ia terbina berdasarkan kaedah dan panduan yang sahih tanpa desakan nafsu, maka ia adalah normal. ${ }^{66}$

${ }^{65}$ Al-Būṭī, al-Salafiyyah, 99-106.

${ }^{66}$ Lihat Sa`̄id Hawwā, Jawlāt fì al-Fiqhayn al-Kabīr wa al-Akbar wa Ușülihimā (Kaherah: Maktabah Wahbah, 1981), 85 \& 86. 
Piawaian intipati ajaran Islam ini adalah asas perpaduan ummah. Kejahilan dalam memahami tahaptahap perselisihan ini atau pengabaian terhadapnya bererti mengekalkan bencana perpecahan, sekaligus meruntuhkan kekuatan dari dalam tanpa berpandukan prioriti utama dalam agenda kesatuan dan pemerkasaan ummah.

\section{Manhaj Ilmu Kalam Dalam Mengkhidmati Nas Wahyu}

Generasi sahabat baginda RA tidak memerlukan jaminan ilmiah dalam memahami asas iktikad dan cabang hukum menurut kehendak Allah SWT dan rasulNya. Ini kerana mereka memiliki keistimewaan berbanding generasi Muslim selepasnya iaitu kemahiran penguasaan bahasa Arab yang sunyi daripada sebarang pengaruh `Ajam dan fitrah keIslaman yang jernih lagi sejahtera. ${ }^{67}$

Mereka juga hidup pada zaman penurunan al-Qur'ān sebagai sumber asas akidah yang berperanan membina akidah yang sahih dan meruntuhkan iktikad yang palsu. Baginda SAW juga turut berperanan menyampaikan akidah yang diwahyukan, memperincikan keumuman alQur'ān dan menangani isu akidah yang timbul. Semasa kehidupan baginda SAW, para sahabat tidak menceburi perbahasan ketuhanan dan sifatNya serta qadak dan qadar selain mengimani kandungan al-Qur'ān dan keterangan alSunnah.

Namun, selepas kewafatan baginda SAW terdapat dua sebab kemunculan aliran bidaah iktikad selepas kewafatan baginda SAW iaitu faktor politik yang melahirkan mazhab Shī’ah, Khawārij dan Murji'ah serta faktor perbincangan akidah yang melahirkan mazhab Qadariyyah dan Jabariyyah atau Jahmiyyah berhubung isu perbuatan manusia, juga mazhab Mu aț̣ilah dan

${ }^{67}$ Al-Būṭ̂̄, al-Salafiyyah, 27 \& 28. 
Mujassimah atau Mushabbihah berhubung isu sifat-sifat Allah SWT. ${ }^{68}$

Pembukaan wilayah Islam yang baru juga mengakibatkan ramai penganut Yahudi, Kristian dan Majusi memeluk Islam. Terdapat kalangan mereka yang ikhlas dan cuba memahami Islam tetapi masih tersisa dengan kepercayaan agama lama sehingga tercetus perdebatan dalaman umat Islam. Sebahagiannya pula pura-pura menzahirkan keIslam dan menyembunyikan agama asal dengan motif merosakkan akidah dan menyemai 'benih' keraguan melalui penyebaran fahaman yang menyesatkan, manakala situasi masyarakat awam yang jahil dan lemah iman, sandaran palsu kepada baginda SAW dan ketebalan ajaran berhala Jahiliah memburukkan lagi keadaan. ${ }^{69}$

Situasi ini membentuk sikap para sahabat kepada dua pendekatan yang berbeza. Pertama; sikap berdiam diri dengan menjauhi perdebatan dan menganggapnya sebagai bidaah yang mungkar. Mereka termasuk 'Umar alKhaț̣āb, `Abd Allāh bin `Umar dan Zayd bin Thābit yang diwarisi kemudiannya oleh Sufyān al-Thawrī, al-Awzā' $\overline{1}$, Mālik bin Anas dan Aḥmad bin Hanbal dalam kalangan tabiin dan generasi berikutnya. Kedua; sikap mengkaji, berbincang dan menangani kekeliruan yang timbul. Mereka termasuk 'Alī bin Abi Țālib, `Abd Allāh bin 'Abbās dan 'Abd Allāh bin Mas'ūd yang diwarisi kemudiannya oleh al-Ḥasan al-Bașrī, Abū Ḥanīfah, alḤārith al-Muhāsibī dan Abū Thawr dari kalangan tabiin dan generasi berikutnya. ${ }^{70}$

Pembentukan ilmu kalam yang mencenderungi pendekatan kedua tersebut terserlah melalui usaha pembaharuan Imam al-Ash'arī dalam mengeksploitasi

\footnotetext{
${ }^{68}$ Muḥammad Rabī' Muḥammad Jawharī, Iqtināṣ al-`Awālī min Iqtisād al-Ghazāli (t.tp.: Dār al-Г tișām, 1998), 12.

${ }^{69}$ Al-Būṭī, al-Salafiyyah, 151.

${ }^{70}$ Ibid., 151.
} 
ilmu kalam sebagai benteng memelihara akidah tauhid. Sebelumnya ilmu kalam didominasi oleh bidaah $\mathrm{Mu}$ 'tazilah sehingga mengakibatkan kerenggangannya daripada ummah seperti yang dapat dilihat dalam pendapat beberapa ahli hadīth dan fuqaha. ${ }^{71}$ Di celah kekeliruan antara Mu'tazilah dengan ahli al-Hadīth dan fuqaha, beliau muncul dengan pendekatan sederhana. Keresahan ummah tentang keutamaan zahir nas dan akal diredakan oleh keistimewaan pendekatannya yang dapat menyeimbangkan keterikatan puak Mushabbihah terhadap zahir nas dan ketakjuban Mu'tazilah terhadap potensi akal. $^{72}$

Melalui kesepaduan akal dan nas ini, yang bersesuaian pula dengan situasi era Mu'tazilah sebelumnya, maka kemurnian tauhid dapat terus

${ }^{71}$ Aḥmad Maḥmūd Șubḥ̄, F̄̄ 'Ilm al-Kalām: al-Ashā ìrah (Beirut: Dār al-Nahḍah, 1985), 43. Punca sebenar penolakan ilmu kalam oleh kalangan ahli hadith salaf masih dianalisis sama ada merujuk kepada dominasi pengaplikasiannya menurut $\mathrm{Mu}$ 'tazilah ketika itu atau merujuk kepada penafian zatnya daripada keluarga ilmu Islam. Ini kerana setelah al-Ash'arī membersihkan ilmu kalam dan mengaplikasikannya demi membela iktikad Ahl al-Sunnah wa alJamā'ah, maka ahli al-Hadith mula mendekati dan mengiktiraf pendekatan ilmu kalam Ashā'irah tersebut. Lihat Ibn 'Asākir, Abū al-Qāsim 'Alī, Tabyīn Kadhb al-Muftarī (Damshiq: Maṭba'ah alTawfìq, 1926).

72 Abdul Shukor Husin, "Asyaari dan Manhajnya" dalam Spektrum Falsafah Islam, ed. Ibrahim Abu Bakar (Kuala Lumpur: Dewan Bahasa dan Pustaka, 1994), 35-36 \& 45-46. Sebagaimana ilmu kalam, konsep takwil turut menjadi mekanisme anjal dalam menyampaikan tujuan atau maqāsid usuluddin demi kepentingan akidah tauhid. Pendekatan salaf Ahmad bin Hanbal yang menolak takwil seperti mana pengisytiharan awal al-Ash'arī menerusi alIbānah 'an Ușūl al-Diyānah tidak berupaya menghadapi penyebaran aliran faham rasional akal yang melanda wilayah Islam. Gejala ini perlu ditangani melalui sandaran akal yang setia berkhidmat kepada nas. Faktor ini menyebabkan beliau tidak dapat bertahan lama dalam beriltizam dengan manhaj salaf yang menolak takwil itu. Lihat `Abd al-Majīd Abū al-Futūh Badawī, al-Tārīkh al-Siyāsī wa al-Fikrī (Mansurah: Dār al-Wafā', 1988), 33-34. 
dipertahankan dan disebarkan. Kesederhanaan pendekatan ini menyebabkan ia mudah diterima, bahkan diterima sebahagian besar masyarakat Islam sehingga kini. Manhaj Ash`ariyyah melayakkan mereka memimpin gerakan pemikiran, sekaligus mencorakkan lanskap politik dalam menyaingi Shī’ah pada kurun kelima sehingga kejatuhan Baghdad. Ketika itu, sikap Mālikiyyah dan Hanābilah yang menolak takwil serta membeku pada zahir nas tidak bermaya menunaikan fungsi ini. ${ }^{73}$

Ahl al-Sunnah wa al-Jamā'ah mendukung keseimbangan dalil akliah (aqlī) dan nas wahyu (naqlī) sebagaimana manhaj Imam al-Ash`arī setelah meninggalkan Mu`tazilah. Dalam al-Ibānah `an Ușūl alDiyānah, ditegaskan bahawa al-Qur'ān, al-Sunnah, riwayat sahabat, tabiin dan imam al-Hadīth adalah pegangan asas agama beliau, manakala dalam Istiḥsān alKhaw đ̣ fī 'Ilm al-Kalām, dikritik pula mereka yang membudayakan taklid dan kejahilan sebagai asas pemikiran. $^{74}$

Jika ungkapan awal menekankan kepentingan berpegang kepada nas persis sikap Imam Aḥmad bin Hanbal dan manhaj salaf sebelum bertapaknya Mu'tazilah, maka ungkapan berikutnya mengisyaratkan penentangan

${ }^{73}$ Al-Ghazalī adalah antara 'produk' era ini. Lihat al-Badawī, al-Tārīkh al-Siyāsī wa al-Fikrī, 184 \& 185.

${ }^{74}$ Menurut Fawqiyah Husayn, al-Ibānah 'an Ușūl al-Diyanah dikarang terlebih dahulu daripada al-Luma' kerana diskusi al-Luma' lebih terperinci berbanding al-Ibānah. Al-Ibānah juga berupa pengisytiharan sikap beliau menyertai Aḥmad bin Hanbal. Lihat Abū al-Hasan `Ali bin Ismāil al-Ash `ari, al-Ibānah 'an Ușūl al-Diyānah, sunt. Fawqiyah Ḥusayn Maḥmūd (Kaherah: Dār al-Ansār, 1977), 78. Pandangan ini disokong oleh Wan Mohd Shaghir bahawa al-Luma' memperluas dan memperjelas kandungan al-Ibānah. Seolah-olahnya, al-Ibānah menempati kedudukan matan, manakala al-Luma` pula adalah syarahnya. Justeru, al-Ibānah dikarang lebih dahulu daripada al-Luma: Lihat Wan Mohd Saghir Abdullah, Wawasan Pemikiran Islam Ulama Asia Tenggara (Kuala Lumpur: Khazanah Fathaniyah, 2002), 135. 
beliau terhadap kejumudan fikiran dan penggunaan potensi akal dalam mengukuhkan akidah yang dibawa oleh nas. Nas lebih berwibawa berbanding akal, manakala akal berperanan mengkhidmati nas tentang hakikat kebenaran akidah.

Wahyu tetap unggul mengatasi akal, bahkan menjadi sandaran rujukan berhubung daerah kelemahan akal dalam bidang metafizik dan sistem nilai. Namun, manhaj alAsha`rī tidak mengabaikan aras kepastian akal yang berupa potensi keintelektualan yang tabii. Daerah kekuatan akal ini dieksploitasi semaksima mungkin dalam menyusun logik demi menghujahi kepalsuan dan pengeliruan musuh, lantaran hukum akal yang pasti dilihat tidak menyalahi perkhabaran nas wahyu yang sahih.

Pendalilan akidah al-Ash arī mengisbatkan kandungan ajaran al-Qur'ān dan al-Hadīth terlebih dahulu, lantas menjurus kepada dalil akal dan burhan mantik sebagai dalil kebenaran ajaran itu secara akliah selepas kewajipan pembenarannya sebagai perkhabaran wahyu. Akal bukan hakim ke atas nas tetapi khadam yang berkhidmat meneguhkan pernyataan nas. ${ }^{75}$

75 Abū Zahrah, Tārikh al-Madhāhib al-Islāmiyyah (Kaherah: Dār alFikr al- 'Arabī, t.th.), 158. Ilmu akidah yang melibatkan unsur mantik ini dikenali sebagai ilmu kalam. Contohnya ayat 22 dan 23, surah alQiyāmah menyatakan:

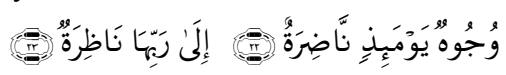

Terjemahan: Wajah-wajah (orang Mukmin) pada hari itu (Akhirat) berseri-seri. Kepada Tuhannyalah mereka melihat.

Ayat ini difahami secara zahir nasnya oleh Asha irah dengan mengisbatkan keharusan melihat Allah SWT pada hari akhirat. Lantas, disusun premis hujah akal berikut: i) Allah SWT maujud, ii) Setiap maujud sah dapat untuk dilihat, maka iii) Allah SWT sah dapat untuk dilihat. Inilah contoh ilmu kalam yang terpuji (mamduh). Sebaliknya, berdasarkan neraca akal, Mu tazilah menafikan keharusan melihat Allah SWT di akhirat terlebih dahulu. Mereka menyusun premis berikut: i) Allah SWT bukan jisim, ii) Setiap yang bukan berjisim tidak dapat dilihat, maka iii) Allah SWT tidak dapat dilihat. Inilah contoh ilmu kalam yang tercela (madhmūm). Lihat 
Ilmu kalam Ashā'irah berintipatikan hukum ketuhanan dan pengutusan rasul menurut hukum akal yang wajib, mustahil dan harus. ${ }^{76}$ Dalam mengisbatkan kewujudan Allah SWT dan sifatNya yang sempurna, ilmu kalam berdalilkan makhluk ciptaanNya yang juga diambil daripada nas syarak. ${ }^{77}$ Ini kerana Allah SWT tidak dapat dikenali melainkan melalui sifatNya, manakala mengenal hakikat zatNya adalah mustahil. ${ }^{78}$ Bahkan, maksud mengenal sifatNya bukan bererti mengenal hakikat sifatNya kerana ini juga mustahil, bahkan ia bererti mengenal sebahagian hukum berkaitan sifat tersebut. ${ }^{79}$

Dakwaan bahawa tiada sebarang ciri ketuhanan Allah SWT berupaya diketahui melalui qiyās mantik ${ }^{80}$ adalah kurang tepat. Ini kerana hukum berhubung ketuhananNya seperti sifat kudrat dan ilmu memang dapat dicapai melalui metode deduksi. Sebaliknya, apa yang mustahil diketahui adalah hakikat sifat tersebut, lantaran daya tanggapan manusia hanya terbatas kepada hakikat segala maujudat yang berstatus mungkin (mumkin al-wujūd) sahaja sedangkan Allah SWT tidak bersifat demikian. ${ }^{81}$

Ilmu kalam juga memanfaatkan dilālah al-iltizām yang terbukti kebenaran pelazimannya, lantas layak dijadikan burhān berhubung persoalan ketuhanan. Kewujudan Allah SWT misalnya dapat dibuktikan oleh

Șalāh Maḥmūd al- 'Adīlī, al-Mantiq al-Tatbīqī (t.tp.: t.p., 2010), 25 $\& 26$.

76 Ismā'ìl bin Mūsā al-Hāmīdī, Hawash ‘alā Sharh al-Kubrā li alSanūsī (Mesir: Maṭba`ah al-Halabī, 1936), 96.

77 -Abd Allāh al-Hararī, Sarīḥ al-Bayān fi al-Radd `alā man Khalafa alQur'ān (t.tp.: Dār al-Mashāri', 2002), 17.

${ }^{78}$ Hasan al-Huwaynī, Qaḍiyyah al-Sifāt al-Ilahiyyah (Kaherah: Dār alHudā, 1986), 33.

79 Sa`īd 'Abd al-Latịif Fūdah, Tahdhīb Sharh al-Sanūsiyyah:Umm alBarāhīn ('Amman: Dār al-Rāzī, 2004), 29.

${ }^{80}$ Iaitu sebagaimana dakwaan Ibn Taymiyyah. Lihat Sa`īd Fūdah, Tad `̀m al-Manțiq (`Amman: Dār al-Rāzī, 2002), 110.

${ }^{81}$ Sa`īd Fūdah, Tad '̌̀m al-Mantiq, 110. 
sejumlah prinsip yang berstatus kelaziman yang jelas ( $a l$ talāzum al-bayyin) iaitu palsunya pemberatan (al-rajhāan) tanpa pemberat (murajjih), palsunya rantaian tanpa penghujung (al-tasalsul) dan palsunya kitaran temu (aldawr). ${ }^{82}$

Jelaslah, ilmu kalam adalah berasaskan kaedah Islam, bukan berdasarkan prinsip ahli falsafah ketuhanan. Pendalilannya berasaskan penyaksian akal terhadap kesahihan ajaran baginda SAW, bukan berasaskan spekulasi akal. Akal berperanan sebagai saksi kepada syarak, bukan sebagai sumber agama. Pandangan akal yang sejahtera tidak bercanggah dengan syarak. ${ }^{83}$ Menurut al-Ghazālī, ajaran Rasululah S`AW mengimbangkan tuntutan syarak dan akal sehingga tiada percanggahan di antara syarak yang dinukilkan (al-shar'u al-manqūl) dengan kebenaran yang waras (al-haqq al-ma ‘qül).

Justeru, kaedah dalam berakidah dan kesederhanaan dalam berpegang kepada kebenaran iaitu tanpa berpada dengan kebekuan dan taklid dalam memahami pernyataan nas - seperti Hashawiyah - dan tanpa boros kepada kendali akal sehingga merempuh aspek syarak yang asas seperti Mu tazilah - . Sebaliknya, akal - yang pasti - ibarat mata yang sejahtera daripada kecacatan, manakala wahyu ibarat matahari yang memancarkan cahaya. Justeru, gandingan akal dengan syarak seumpama cahaya di atas cahaya. ${ }^{8}$

Dalam konteks ini, al-Ghazālī memilih sikap yang sederhana dalam menilai status ilmu kalam yang dilihat mempunyai sisi manfaatnya dalam konteks memelihara akidah daripada pengeliruan ahli bidaah. Namun begitu, terdapat juga sisi mudaratnya dalam konteks mencetuskan syubhah dan mengukuhkan iktikad bidaah. Aplikasi ilmu kalam wajar mengutamakan keperluan masyarakat awam

\footnotetext{
${ }^{82}$ Al-Būṭī, Kubrā al-Yaqīniyyāt al-Kawniyyah, 79.

${ }^{83}$ Al-Hararī, Sarīḥ al-Bayān, 17.

${ }^{84}$ Al-Ghazālī, al-Iqtișād fì al-I tiquād, 9 \& 10.
} 
sama ada mereka diliputi pengeliruan ahli bidaah sehingga menuntut khidmat ilmu tersebut, atau memadai bagi mereka dengan metode pengajaran al-Qur'ān dan alHadīth, lantaran kesejahteraan akidah mereka kekal terpelihara tanpa perlu disibukkan dengannya. Keadaan ini menuntut penilaian persis kecerdikan doktor yang membekalkan ubat menurut waktu dan kadar keperluannya. $^{85}$

Menurut al-Ghazālī, pendalilan ilmu kalam berfungsi sebagai ubat penawar bagi penyakit syubhah ahli bidaah. Dua golongan yang tidak memerlukan ilmu kalam ialah mereka yang telah sedia mengiktikadkan kebenaran Allah SWT dan RasulNnya SAW tanpa taklid atau diulit keraguan, juga pendukung kesesatan yang fanatik lagi bebal akalnya. Sebaliknya, dua golongan lagi berpotensi untuk dijinakkan dengan hujah ilmu kalam iaitu mereka yang mengiktikadkan kebenaran Allah SWT dan RasulNya SAW tetapi masih diganggu syubhah, juga pendukung kepalsuan yang memiliki kecerdasan dan bersedia menerima hujah kebenaran. ${ }^{86}$

Mendalami ilmu kalam bukan termasuk dalam fardu ain tetapi berupa fardu kifayah. Apa yang wajib ialah pembenaran putus dan pembersihan hati daripada keraguan dalam iman sebagaimana menghilangkan syak adalah fardu ain bagi mereka yang terganggu olehnya. ${ }^{87}$ Sesiapa yang meragui asas akidah dan tiada jalan melepasinya melainkan dengan hujah ilmu kalam, maka hukum mempelajarinya adalah wajib. ${ }^{88}$ Ia penting bagi tujuan dakwah dan pembendungan syubhah ahli bidaah. Tatkala masyarakat Islam tidak melepasi cabaran ini,

${ }^{85}$ Abū Hāmid Muhammad bin Muhammad al-Ghazāli, Ihyā' 'Ulūm alDìn (Kaherah: Dār al-Hadīth, 1992), 156 \& 157.

${ }^{86}$ Ibid., 14 \& 15.

${ }^{87}$ Ibid., 16 \& 17.

${ }^{88}$ Muhy al-Dīn Yahyā al-Nawāwī, Kitāb al-`Ilm wa Adāb al-`Alim wa al-Muta allim (Beirut: Dār al-Khayr, 1993), 80 \& 81. 
maka wajib terdapat penegak kebenaran yang menceburi ilmu ini sebagaimana perlunya ahli masyarakat kepada doktor dan ahli fiqah. ${ }^{89}$

Prospek masa depan ilmu kalam tidak wajar dipersiakan ketika umat Islam sedang kritikal diserang oleh penyerapan falsafah dan ideologi moden Barat atas nama Pemikiran Islam. Ilmu kalam baru perlu berperanan menjelaskan perkaitan antara Allah, alam, manusia dan kehidupan menurut perspektif akidah yang digugat oleh pandangan alam Barat yang asing. Tema pemikiran dan falsafah iaitu epistemologi, ontologi atau metafizik serta aksiologi atau perbahasan sistem nilai perlu menjadi tumpuan ilmu kalam kontemporari ini. ${ }^{90}$ Kewajipan semasa menuntut usaha penyingkapan ancaman baru tersebut yang meragui kelayakan panduan Islam dalam menyelesaikan krisis manusia. ${ }^{91}$ Maksud ini dicapai melalui penolakan ukuran dan konsep agama untuk digantikan dengan ukuran dan konsep baru yang bersumberkan falsafah dan ideologi Barat. $^{92}$

${ }^{89}$ Al-Ghazālī, al-Iqtiṣād fi al-I tiqāed, 16 \& 17.

${ }^{90}$ Kepentingan ilmu kalam kontemporari ini dibahaskan oleh Ṭahā alDusūqī dalam ‘Aqidatunā wa Șilatuhā bi al-Kawn wa al-Insān wa al-Hayāh, 'Alī 'Abd al-Fattāḥ al-Maghribī dalam al-Firaq alKalāmiyyah al-Islāmiyyah: Madkhal wa Dirāsah dan `Abd al-Majīd al-Najjār dalam Mabāhith fì Manhajiyyah al-Fikr al-Islāmiyy.

91 Hasrat mereka ialah mernyemai keraguan terhadap nilai ilmiah manhaj ulama dalam menafsirkan nas agama, sekaligus menggugat kewibawaan institusi ulama dalam memimpin ummah. Kemuncak daripada krtikan itu, maka dikemukakan pula teori dan panduan sosial yang selari dengan ideologi moden Barat. Lihat karya seperti Teori Sosial Moden Islam (1984), Al-Hadith: Jawapan kepada Pengkritik (1992) dan Mencari Jalan Pulang: Daripada Sosialisme Kepada Islam (2008). Demikian juga jalur pemikiran PostModenisme yang sedang menular dalam masyarakat masa kini.

92 Zulkifli Ismail, Ancaman Bahaya Sekularisme, 263 \& 264. Tugas ini telah dipikul oleh ulama akidah Universiti al-Azhar melalui karya alTayyārāt wa al-Madhāhib al-Mu'așirah dan al-Șirā' bayn alThaqāfah al-Islāmiyyah wa al-Thaqāfāt al-Ukhrā oleh Țahā alDusūqī, Iflās al-Fikr al-Markasī: Dirāsah Naqdiyyah oleh `Abd al- 


\section{Kesimpulan dan Penutup}

Manhaj akidah Ahl al-Sunnah wa al-Jamā’ah mewakili pemikiran Islam yang tulen. Tanpa benteng ini, ummah terdedah kepada ancaman kekufuran dan pengeliruan bidaah iktikad. Kematangan wacana akidah Ahl al-Sunnah wa al-Jamā'ah adalah hasil jihad keintelektualan yang diharungi oleh para ulamanya dalam mendepani cabaran akidah klasik. Pembentukan manhaj periwayatan, penafsiran dan istinbāt mereka terhadap nas dan sumber agama dinatijahkan oleh sifat amanah ilmu para ulamanya yang amat tinggi dan berkualiti. Justeru, tidak hairanlah kefahaman Ahl al-Sunnah wa al-Jama'āh amat serasi dengan akal yang pasti lagi ditenangi oleh jiwa sehingga disambut oleh majoriti ummah sebagai tafsiran yang berautoriti terhadap maksud al-Qur'ān dan al-Hadīth.

Ciri keistimewaan manhaj ini dapat menjelaskan kelayakan Ahl al-Sunnah wa al-Jamā'ah sebagai paksi kesatuan ummah dalam konteks penerimaan prinsip Usuluddin yang paling mendasar. Pertikaian kalangan umat Islam terhadap manhaj Ahl al-Sunnah wa al-Jamā`ah yang diparahkan pula dengan perselisihan sesama 'keluarga besar' Ahl al-Sunnah wa al-Jamā'ah berhubung isu cabang akidah wajar ditangani secara berhikmah ibarat "menarik rambut dalam tepung" menurut panduan ilmu, manakala kepungan konspirasi Zionisme, Kristianisasi, Sekularisme, Post-Modenisme, Ateisme dan kuncukuncunya amat menuntut keseriusan dalam menekuni kembali tradisi manhaj Ahl al-Sunnah wa al-Jamā`ah dengan orientasi pengajian akidah yang relevan dengan

Faḍil al-Qūsī, al-Wujūdiyyah: bayn al-Ya's wa al-`Adam oleh Țala`at Ghanam dan al-Fikr al-Māddi al-Hadith wa Mawqif al-Islām minh oleh Mahmud Uthmān, juga ulama didikan akidah al-Azhar seperti al-Islām fi Muwājahah al-Aydiyūlujiyyāt al-Mu āṣirah oleh ‘Abd al-'Az̄ìm al-Maṭ’an̄̄, Kubrā al-Yaqīniyyāt al-Kawniyyah: Wujūd al-Khāliq wa Wazīfah al-Makhlūq dan Naqd Awhām alMāddiyyah al-Jadaliyyah oleh al-Shahīd Muhammad Sa`īd Ramaḍān al-Būṭī. 
ancaman ideologi, falsafah dan pemikiran semasa - itulah agenda dan prospek baru usuluddin.

\section{Rujukan}

‘Abd al-Ghazānī, Hassan. Dirāsāt fì al-'Aqīdah alIslāmiyyah: al-Sam ìyyāt. Kaherah: Maṭba`ah alHusayn al-Islāmiyyah, 1998.

Abdul Shukor Husin. "Asyaari dan Manhajnya." Dalam Spektrum Falsafah Islam, ed. Ibrahim Abu Bakar. Kuala Lumpur: Dewan Bahasa dan Pustaka, 1994.

Abū Zahrah. Tārikh al-Madhāhib al-Islāmiyyah. Kaherah: Dār al-Fikr al-'Arabī, t.t.

Al-`Adīlī, Șalāh Maḥmūd. Al-Manțiq al-Tatbīqī. t.tp.: t.p., 2010.

Aḥmad bin Hanbal, al-Bukhāriyy, Ibn Qutaybah \& alDārimiyy. 'Aqū ’id al-Salaf, sunt. 'Alī Sāmī al-Nashshār \& 'Ammar Jām'i al-Ṭālibī. Iskandariah: Mansha'ah alMa`ārif, 1971.

Ahmmad bin Muhammad Zayn bin Mușțafā bin Muhammad al-Fatānī. Farīdah al-Farā ìd fì 'Ilm al- 'Aqā'id. Pulau Pinang: Persama, 1951.

Al-Ash arì, Abū al-Hasan `Ali bin Ismāil. Al-Ibānah 'an Ușūl al-Diyānah, sunt. Fawqiyah Husayn Maḥmūd. Kaherah: Dār al-Ansār, 1977.

Al-Ash`arī, Abū al-Hasan `Alī. Risālah Istihsā̄n al-Khawd fí 'Ilm al-Kalām. Beirut: Dār al-Mashāri', 1995.

Badawī, 'Abd al-Majīd Abū al-Futūḥ. Al-Tārīkh al-Siyās̄̄ wa al-Fikrī. Mansurah: Dār al-Wafā', 1988.

Al-Baghdādī, 'Abd al-Qāhir bin Tāhir bin Muḥammad. Al-Farq bayn al-Firaq. Maydān al-Azhar: Maktabah Muḥammad `Alī Șubayh wa awlāduh, t.t.

Al-Būṭ̣̂, Muḥammad Sa īd Ramaḍān. Kubrāa al-Yaqīniyyāt al-Kawniyyah: Wujūd al-Khāliq wa Ważĭfah alMakhlūq. Dimashq: Dār al-Fikr, 1990.

Al-Būṭị, Muḥammad Sa īd Ramaḍān. "Azmah al-Ma rifah wa 'Ilājuhā fī Hayātinā al-Fikriyyah al-Mu'āṣirah." Dalam al-Manhājiyyah al-Islāmiyyah wa al- 'Ulūm al- 
Sulūkiyyah wa al-Tarbawiyyah. Virginia: al-Ma`had al'Ālami li al-Fikr al-Islāmī, 1990.

Al-Būṭ̂̄, Muhammad Sa`̄id Ramaḍān. Al-Salafiyyah: Marhalah Zamāniyyah Mubārakah Lā Madhhab Islāmiyy. Dimashq: Dār al-Fikr, 1998.

Al-Farfūr, Muhammad 'Abd al-Lațîf Sāliḥ. Mi yār alMa āyir aw Ușūl al-Khilāf al-'Ilmī. Dimashq: Dār alMa'mūn li al-Turāth, 1988.

Al-Fațān̄̄, al-Fāḍil Umar bin Zayn al- 'Ābidīn. "Asbāb alMurtad.” Dalam Majmū ah al-Tawhīd. Miṣr: Mușțafā al-Bābī al-Halabīe 1936.

Al-Ghazāli, Abū Hāmid Muḥammad bin Muḥammad. Ihyā' 'Ulūm al-Dìn. Kaherah: Dār al-Hadīth, 1992.

Al-Ghazālī, Abū Hāmid Muḥammad bin Muḥammad. Fayșal al-Tafrīqah bayn al-Islām wa al-Zanādiqah. Beirut: Dar al-Fikr al-Lubnani, 1993.

Al-Ghazālī, Abū Hāāmid Muḥammad bin Muḥammad. AlIqtișād fì al-I tiqqād. Beirut: Dār al-Kutub al-'Ilmiyyah, 2004.

Al-Ḥāmīdī, Ismā'̄il bin Mūsā. Hawash ‘alā Sharh alKubrā li al-Sanūsī. Miṣr: Maṭba ah Mușțafā al-Bābī alHalabī, 1936.

Al-Hararī, ’Abd Allāh. Al-Sharḥ al-Qawìm fi Hall Alfāz al-Șirāt al-Mustaqīm. Beirut: Dār al-Mashārī', 1999.

Al-Hararī, 'Abd Allāh. Sarīh al-Bayān fi al-Radd ‘alā man Khalafa al-Qur'ān. t.tp.: Dār al-Mashāri', 2002.

Al-Huwaynī, Hasan. Qadìyah al-Sifāt al-Ilahiyyah wa Atharuhā fì Tasha ub al-Madhāhib wa Ikhtilāf al-Firaq. al-Sayyidah Zaynab: Dār al-Hudā, 1986.

Al-Huwaynī, Hasan. Qaḍiyyah al-Sifāt al-Ilahiyyah. Kaherah: Dār al-Hudā, 1986.

Ibn 'Asākir, Abū al-Qāsim 'Alī. Tabyīn Kadhb al-Muftarī. Damshiq: Maṭba'ah al-Tawfĩq, 1926.

Jalāl al-Dìn 'Abd al-Raḥman. Al-Ijtihād: Dawābițhu wa Ahkāmuh. t.tp.: t.p., 1986. 
Jawharī, Muḥammad Rabī' Muhammad. 'Aqīdatunā (Juz`u al-Thānī). t.pt.: t.p., 2007.

Jawharī, Muhammad Rabī̄ Muhammad. Iqtināṣ al-`Awālī min Iqtisād al-Ghazāli. t.tp.: Dār al-I'tișām, 1998.

Al-Jund̄̄, Anwār. Naḥw Binā' Manhaj al-Badā'il alIslāmiyyah. Kaherah: Dār al-I'tișām, t.t.

Al-Kattān̄̄, al-Sayyid Muḥammad bin Ibrāhīm bin `Abd al-Bā 'ith al-Husaynī. Ibrā' al-Dhimmah bi Tahqūiq alQawl hawl Iftirāq al-Ummah. Al-Ghardaqah: Dār alSafwah, 1997.

Al-Kūbī, Sa`d al-Dīn bin Muḥammad. Dawābit al-takfìr `ind Ahl al-Sunnah wa al-Jamā'ah. Beirut: al-Maktab al-Islāmī, 1997.

Khafājī, `Abd al-Mun `im. Al-Mu jam al-Falsafï. Kaherah: al-Dār al-Sharqiyyah, 1990.

Lajnah min Asātizah Qism al-'Aqīdah wa al-Falsafah bi Kulliyyah Ușūl al-Dīn - Jāmi`ah al-Azhar, Ușūl al'Aqūdah al-Islāmiyyah wa al-Akhlāq. Al-Dirāsah: Maktabah al-Azhar, 1972.

Al-Maṭ’anī, 'Abd al- 'Aẓim. Hadhā Bayān li al-Nās: alShubuhāt al-Thalathūn al-Mathārah li Inkār al-Sunnah al-Nabawiyyah. Kaherah: Maktabah Wahbah, 1999.

Muhammad Wahbī bin Husayn Afandī. Al- 'Aqā'id alKhayriyyah. t.tp.: Dār Ihyā', t.t.

Al-Mu jam al-Falsafi. Kaherah: Majma` al-Lughah al'Arabiyyah, 1979.

Mūsā, Jalāl Muhammad. Nash'ah al-Ash'ariyyah wa Tațawwuruhā. Beirut: Dār al-Kutub al-Lubnān̄̄, 1975.

Mustika al-Hadith (jil. dua). Kuala Lumpur: Majlis Kebangsaan Hal Ehwal Agama Islam, Jabatan Perdana Menteri, 1984.

Al-Nadawī, Abū al-Ḥasan 'Alī. Rijāl al-Fikr wa alDa 'wah fì al-Islām (al-Juz'u al-Awwal). Kuwait: Dār al-Qalam, 1989.

Al-Nashshār, 'Alī Sāmī. Nash'ah al-Fikr al-Falsafī fi alIslām. Kaherah: Dār al-Ma ārif, t.t. 
Al-Nawāwī, Muhy al-Dīn Yahyā. Kitāb al-`Ilm wa Adāb al-`Alim wa al-Muta allim. Beirut: Dār al-Khayr, 1993.

Qandīl, Muhammad Qandīl. Tahlīl wa Takmīl: al-Iqtiṣād fì al-I'tiqūd. Kaherah: Dār al-Ṭibā'ah alMuhammadiyyah, 1991.

Al-Qaraḍāwī, Yūsūf. Hudā al-Islām: Fatāwā Mu'āsarah. Kuwait: Dār al-Qalam, 1990.

Al-Qaraḍāwī, Yūsuf. Al-Ijtihād fì al-Sharīah alIslāmiyyah. Kuwait: Dār al-Qalam, 1996.

Al-Qarāḍawī, Yūsuf. Al-Sunnah Mașdaran li al-Ma`rifah wa al-Had̄ārah. Kaherah: Dār al-Shurūq, 1998.

Sa`īd 'Abd al-Lațîf Fūdah. Tahdhīb Sharh alSanūsiyyah:Umm al-Barāhīn. 'Amman: Dār al-Rāzī, 2004.

Sa`īd `Abd al-Lațîf Fūdah. Tad ’̀m al-Manțiq. `Amman: Dār al-Rāzī, 2002.

Sa `̄d Hawwā. Jawlāt fì al-Fiqhayn al-Kabīr wa al-Akbar wa Ușūlihimā. Kaherah: Maktabah Wahbah, 1981.

Sa`īd Ḥawwā. Al-Islām. `Amman: Dār `Ammār, 1988.

Sa`̄id Hawwā. Tarbiyyatunā al-Rūhiyyah. Beirut \& Amman: Dār `Ammār, 1989.

Sa`īd Hawwā. Al-Asās fi al-Sunnah wa Fiqhihāa: al'Aqā'id al-Islāmiyyah (al-mujallad al-awwal). Shāri' al-Azhar: Dār al-Salām, 1992.

Al-Sāwī, Aḥmad bin Muḥammad. Kitāb Sharh al-Sāwwī alā Jawharah al-Tawhīd. Beirut: Dār Ibn Kathīr, 2005.

Al-Sayyid Șālị̣, Sa`d al-Dīn. Al- 'Aqīdah al-Islāmiyyah fì Daw' al-'Ilm al-Hadìth. Kaherah: Dār al-Ṣafā, 1991.

Al-Shāfì '̄, Hasan Mạ̣mūd. Al-Madkhal ilā Dirāsah 'Ilm al-Kalām. Kaherah: Maktabah Wahbah, 1991.

Al-Sajustānī, Abū Dāwud Sulaymān bin Ash 'ath al-Azadī. Awwal Kitāb al-Sunnah, Bāb fì Luzūm al-Sunnah, alHadīth no. 4607, Mawsu'ät al-Hadìth al-Sharîf alKutub al-Sittah. Riyadh: Dār al-Salām, 2000. 
Al-Shahrastān̄̄, Muhammad bin `Abd al-Karīm bin Abū Bakr Aḥmad. Al-Milal wa al-Nihal. Beirut: Dār alKutub al-'Ilmiyyah, 2001.

Al-Sinān, Hamād dan al-`Anjariyy, Fawzī. Ahl al-Sunnah al-Ashā 'irah: Shahādah 'Ulamā' al-Ummah wa Adillatuhum. Kuwait: Dār al-Diyā', 2006.

Șubḥ̄̄, Aḥmad Mạ̣mūd. F̄̄ 'Ilm al-Kalām: al-Ashā irah. Beirut: Dār al-Nahḍah, 1985.

Al-Ṭabrān̄̄, Abū al-Qāsim Sulaymān bin Aḥmad. Bāb al'Ayn, al-Hadīth no. 13623, al-Mu ’jam al-Kabìr (juz' 10). t.tp.: Maktabah al-Aṣālah wa al-Turāth, 2010.

Wan Mohd Saghir Abdullah. Wawasan Pemikiran Islam Ulama Asia Tenggara. Kuala Lumpur: Khazanah Fathaniyah, 2002.

Yahyāa, 'Abd al-Ghan̄̄ \& Yūsuf, 'Umar. Risālah alTawhīd. t.p: t.pt., t.th.

Al-Zuhaylī, Wahbah. Ușūl al-Fiqh al-Islāmī (al-juz'u alawwal). Dimashq: Dār al-Fikr, 1986.

Zulkifli Ismail. Ancaman Bahaya Sekularisme. Sungai Udang: Baitul Qurra', 2002. 